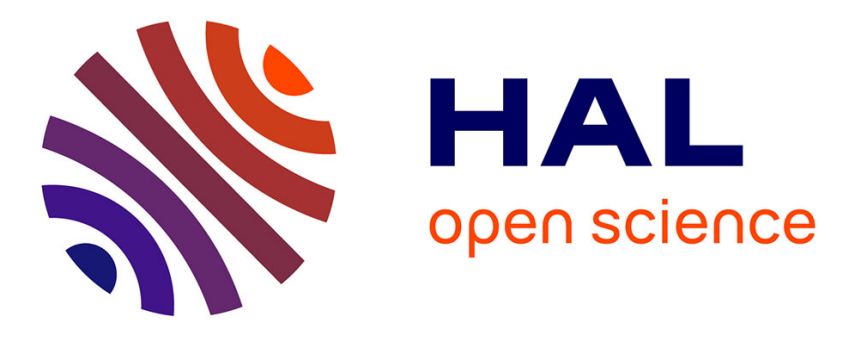

\title{
Modeling the migration of fallout radionuclides to quantify the contemporary transfer of fine particles in Luvisol profiles under different land uses and farming practices
}

\author{
M. Jagercikova, O. Evrard, J. Balesdent, I. Lefevre, S. Cornu
}

\section{To cite this version:}

M. Jagercikova, O. Evrard, J. Balesdent, I. Lefevre, S. Cornu. Modeling the migration of fallout radionuclides to quantify the contemporary transfer of fine particles in Luvisol profiles under different land uses and farming practices. Soil and Tillage Research, 2014, 140, pp.82-97. 10.1016/j.still.2014.02.013 . hal-01458016

\author{
HAL Id: hal-01458016 \\ https://hal.science/hal-01458016
}

Submitted on 26 May 2020

HAL is a multi-disciplinary open access archive for the deposit and dissemination of scientific research documents, whether they are published or not. The documents may come from teaching and research institutions in France or abroad, or from public or private research centers.
L'archive ouverte pluridisciplinaire HAL, est destinée au dépôt et à la diffusion de documents scientifiques de niveau recherche, publiés ou non, émanant des établissements d'enseignement et de recherche français ou étrangers, des laboratoires publics ou privés. 
1 Modeling the migration of fallout radionuclides to quantify the contemporary transfer of

2 fine particles in Luvisol profiles under different land uses and farming practices

$4 \quad$ M. Jagercikova ${ }^{\mathrm{a}}$, O. Evrard ${ }^{\mathrm{b}}$, J. Balesdent $^{\mathrm{a}}$, I. Lefèvre $^{\mathrm{b}}$, S. Cornu $^{\mathrm{a}}$

5 a- INRA, UR1119 Géochimie des Sols et des Eaux, F-13100 Aix en Provence, France (Marianna.Jagercikova@aix.inra.fr;

6 scornu@aix.inra.fr)

7 b- Laboratoire des Sciences du Climat et de l'Environnement (LSCE/IPSL), UMR8212 (CEA-CNRS-UVSQ), Domaine du CNRS, F-

891198 Gif-sur-Yvette Cedex, France (olivier.evrard@1sce.ipsl.fr)

10 Corresponding author: M. Jagercikova, Marianna.Jagercikova@aix.inra.fr, +33 ø4 42908543

\section{Abstract}

12 Soil mixing and the downward movement of solid matter in soils are dynamic pedological 13 processes that strongly affect the vertical distribution of all soil properties across the soil profile.

14 These processes are affected by land use and the implementation of various farming practices, 15 but their kinetics have rarely been quantified. Our objective was to investigate the vertical 16 transfer of matter in Luvisols at long-term experimental sites under different land uses (cropland, 17 grassland and forest) and different farming practices (conventional tillage, reduced tillage and no tillage). To investigate these processes, the vertical radionuclide distributions of ${ }^{137} \mathrm{Cs}$ and ${ }^{210} \mathrm{~Pb}$

19 (xs) were analyzed in 9 soil profiles. The mass balance calculations showed that as much as $91 \pm$ $209 \%$ of the ${ }^{137} \mathrm{Cs}$ was linked to the fine particles $(\leq 2 \mu \mathrm{m})$. To assess the kinetics of radionuclide 21 redistribution in soil, we modeled their depth profiles using a convection-diffusion equation. The 22 diffusion coefficient represented the rate of bioturbation, and the convection velocity provided a 23 proxy for fine particle leaching. Both parameters were modeled as either constant or variable 24 with depth. The tillage was simulated using an empirical formula that considered the tillage 25 depth and a variable mixing ratio depending on the type of tillage used. A loss of isotopes due to 
26 soil erosion was introduced into the model to account for the total radionuclide inventory. All of

27 these parameters were optimized based on the ${ }^{137} \mathrm{Cs}$ data and were then subsequently applied to

28 the ${ }^{210} \mathrm{~Pb}(\mathrm{xs})$ data. Our results show that the ${ }^{137} \mathrm{Cs}$ isotopes migrate deeper under grasslands than 29 under forests or croplands. Additionally, our results suggest that the diffusion coefficient 30 decreased with depth and that it remained negligible below the tillage depth at the cropland sites, 31 below $20 \mathrm{~cm}$ in the forest sites, and below $80 \mathrm{~cm}$ in the grassland sites.

33 Keywords: soil; lessivage; bioturbation; tillage practices; ${ }^{137} \mathrm{Cs} ;{ }^{210} \mathrm{~Pb}$ (xs)

\section{Introduction}

36 Pedogenesis is a non-linear process in time and space (Montagne et al., 2013). Although the 37 occurrence of major pedogenic processes can be easily identified in soil, their chronological 38 succession and their rates are difficult to quantify due to the difficulty of finding relevant tracers 39 to investigate the processes of interest in the appropriate temporal scale. Among these processes, 40 lessivage, which is defined as the migration of fine particles ( $\leq 2 \mu \mathrm{m}$ or lutum fraction) from 41 subsurface horizons (eluviation) and their accumulation in the B horizon (illuviation), has not 42 been quantified, and its kinetics remain poorly understood (Quénard et al., 2011).

43 Lessivage was traditionally described as occurring at a timescale ranging from tens to thousands 44 of years (Jamagne, 1973; Finke and Hutson, 2008). Although some authors considered that 45 lessivage is an ancient pedogenic process that occurred exclusively under warm and humid 46 climates (Jamagne, 1978; Jamagne et Pédro, 1981), Fedoroff (1997) showed that it is still 47 currently active in regions with a Mediterranean climate. Therefore, we decided to study i) the 
48 occurrence of current lessivage in a non-Mediterranean temperate climate and ii) the impact of

49 land use and agricultural practices on this lessivage.

50 Lessivage is considered to be the major pedogenic process occurring in several soil types 51 (Bockheim and Gennadiyev, 2000), mainly in European Luvisol and Albeluvisol soils. These 52 soil types are also particularly widespread in the USA and in China as they develop in all loess 53 deposits. In Europe, these soils cover $20 \%$ of the surface (Jones et al., 2005). Several authors 54 hypothesized that agricultural activities could have a crucial impact on their evolution (Khan et 55 al., 2005; Kühn, 2003; Fedoroff, 1997). Therefore, they represent an ideal case study.

56 Lessivage is not the only pedogenic process that affects vertical solid matter transfers in soils.

57 Other processes that may act in synergy or in opposition to lessivage must be considered. 58 Pedoturbation processes, such as clay shrinking-swelling cycles, soil freezing and bioturbation, 59 tend to mix or, conversely, to segregate soil matter. Bioturbation is the movement of matter in 60 the soil due to the presence of living organisms (Gobat et al., 1998), soil fauna and/or root 61 systems, as well as tree falls (Wilkinson et al., 2010). This has several important consequences 62 on soil structure, such as the mechanical loosening of the soil, the oxygenation of the deepest 63 layers, the redistribution of organic matter, the transport of buried elements to the surface and the 64 neutralization of the $\mathrm{pH}$. In all, it is clear that bioturbation plays an essential role in clay 65 distribution in soils. Although there are many agents that act in bioturbation, in a temperate 66 climate, earthworms are considered to be the main actor (Müller-Lemans and van Dorp, 1996;

67 Gobat et al., 2004; Persson et al., 2007), particularly anecic worms when vertical movement is 68 considered (Persson et al., 2007). 
70 The fallout radionuclides ${ }^{137} \mathrm{Cs}$ and ${ }^{210} \mathrm{~Pb}(\mathrm{xs})$ have different sources in the environment. ${ }^{137} \mathrm{Cs}$

71 was released and dispersed during the nuclear weapon tests that occurred between 1953 and the

72 1970s, as well as by nuclear power plant accidents (Chernobyl in 1986 and Fukushima Dai-ichi

73 in 2011). In contrast, ${ }^{210} \mathrm{~Pb}$ is naturally present because it is a product of ${ }^{238} \mathrm{U}$ decay and is a

74 daughter product of gaseous ${ }^{222} \mathrm{Rn}$. Some ${ }^{222} \mathrm{Rn}$ may escape from the soil and lithosphere and

75 continue to decay in the atmosphere, resulting in ${ }^{210} \mathrm{~Pb}$, which then returns to the Earth's surface

76 through wet fallout. Therefore, this is referred to as unsupported or excess (xs) ${ }^{210} \mathrm{~Pb}$, in contrast

77 to supported ${ }^{210} \mathrm{~Pb}$ that is naturally present in the soil. The fallout radionuclides ${ }^{137} \mathrm{Cs}$ and

$78{ }^{210} \mathrm{~Pb}(\mathrm{xs})$ have been used as tracers in soil studies because they are exclusively of atmospheric

79 origin. Furthermore, they are strongly sorbed to the soil solid phases: ${ }^{137} \mathrm{Cs}$ to clay particles

80 (Tamura and Jacobs, 1960; Sawhney, 1972; Cremers et al., 1988) and ${ }^{210} \mathrm{~Pb}$ to clay particles and

81 organic matter (Dörr and Münnich, 1989). Thus, their transfer occurs only in association with the

82 solid matter in the soils that are not dominated by soluble organic matter transfers (Jarvis et al.,

83 2010; Matisoff et al., 2011). Finally, the choice of these radionuclides was also motivated

84 because their half-lives $\left(30.2\right.$ years for ${ }^{137} \mathrm{Cs}$ and 22.3 years for $\left.{ }^{210} \mathrm{~Pb}\right)$ are favorable for

85 investigating the impact on the transfer processes due to modification in agricultural practices, 86 occurring at a decadal timescale.

87

88 These reasons justify the use of ${ }^{137} \mathrm{Cs}$ and ${ }^{210} \mathrm{~Pb}$ (xs) as suitable tracers for estimating the kinetics 89 of solid matter transfer in soils, including lessivage and bioturbation. Diffusion-convection 90 modeling of the vertical distributions of these radionuclides (e.g., He and Walling, 1997;

91 Schuller et al., 1997) could provide a way to differentiate between these two processes because 92 the diffusion equation, which corresponds to the random mixing (or movement) of matter 
93 upwards and downwards across short distances, is classically associated with bioturbation 94 (Boudreau, 1986; Elzein and Balesdent, 1995; Schiffers et al., 2011), whereas convection as a 95 long distance transport may be associated with lessivage. However, part of the long distance 96 transport may also be associated with bioturbation, such as that resulting from the activity of 97 anecic or epianecic earthworms. This bioturbation may result in more complex processes, such 98 as litter incorporation into deeper layers or, reciprocally, deposits of deep horizon matter at the 99 surface in the form of casts. In the diffusion-convection modeling, long-distance transport by 100 bioturbation was assessed using a supplementary term (Jarvis et al., 2010). Other modeling 101 approaches of worm mixing have been developed based on worm mixing experiments (Barnett et 102 al., 2009; Schiffers et al., 2011). However, the experimental data provided by these studies show 103 that they may be reasonably represented by a diffusion equation.

105 The aims of this study are (1) to quantify the current particle transfer by ${ }^{137} \mathrm{Cs}$ and ${ }^{210} \mathrm{~Pb}$ (xs) in a 106 soil sequence, as defined by Jenny (1941), considering human activity as a pedogenic factor 107 (anthroposequences); (2) to determine the kinetics of these transfers by modeling the vertical 108 distributions of ${ }^{137} \mathrm{Cs}$ and ${ }^{210} \mathrm{~Pb}(\mathrm{xs})$ with a diffusion-convection equation using both constant and 109 depth-dependent coefficients; and (3) to identify the impact of both land use and agricultural 110 practices on the intensity and kinetics of particle transfer in soils.

\section{2. Materials and Methods}


115 We selected three Luvisol sequences from Northern France that experienced different land uses

116 (cultivation, grassland and forest), as land use impacts both the soil $\mathrm{pH}$ and the soil organic

117 matter content, which are known to influence soil particle stability and dispersion (Le Bissonnais

118 and Arrouays, 1997; Chenu et al., 2000). Additionally, two agricultural practices, manure input

119 and tillage reduction were investigated because tillage reduction modifies the preferential flow

120 paths in soils (Dexter, 1993), and this process was shown to be responsible for particle

121 detachment (Majdalani et al., 2007).

122 These sequences were part of long-term experiments conducted to evaluate the impact of 123 different farming practices on soil characteristics (Table 1). They also cover a gradient in $\mathrm{pH}$ 124 (from 7 to 6) and in duration (from 40 to 11 years). The Luvisols developed on Weichselian loess 125 deposits and have an age of 15-16 ka (Antoine et al., 2003); currently, these soils experience a 126 temperate climate (Table 1). The three soils, described in Table 2, differ in depth. Mons's 127 Luvisols were developed on several meters of loess and were, therefore, well drained, whereas 128 clay and gritstone deposits were reached at approximately $1.5 \mathrm{~m}$ depth in the Feucherolles 129 samples, and chalk was reached at approximately $80 \mathrm{~cm}$ depth in the Boigneville samples. The 130 Luvisols in Feucherolles exhibit redoxic features due to a change in parent material at this depth. 131 All sites were sampled in flat conditions ( $<1 \%$ slope). To be comparable within a given site, the 132 three plots were closely situated and in equivalent topographic situations.

\section{$134 \quad$ 2.2. Soil sampling}

135 Sampling was conducted in soil pits by continuous scraping of the soil with clean stainless steel

136 tools. To avoid cross-contamination, the tools were cleaned and dried between each sampling 137 level. Any soil that fell from the higher levels onto the sampling surface was carefully removed. 
138 Each sample consisted of approximately 3 to $4 \mathrm{~kg}$ of bulk soil. The sampling was continuous, 139 with varying sampling increments of $2 \mathrm{~cm}$ to $10 \mathrm{~cm}$ depth. The samples were then oven-dried at $14040^{\circ} \mathrm{C}$ and sieved to $2 \mathrm{~mm}$. The soil bulk densities were determined using the cylinder method for 141 each horizon and using gamma-ray attenuation for surface horizons. The results of the pedologic 142 analysis (the particle-size fractions, organic carbon, $\mathrm{pH}$, exchangeable cations and bulk density) 143 are summarized in Table 3.

\section{$145 \quad$ 2.2.3. Particle-size fractionation}

146 Particles with diameters $\leq 2 \mu \mathrm{m}$ were extracted from certain samples (at least one sample per 147 horizon). These soil subsamples, weighing $150 \mathrm{~g}$, were dispersed in $540 \mathrm{ml}$ of de-ionized water 148 with 20 agate beads ( $5 \mathrm{~mm}$ in diameter) via shaking for $22 \mathrm{~h}$ in an overhead shaker at a speed of $14937 \mathrm{rpm}$. The organic-rich samples subsequently underwent ultrasonic dispersion. The ultrasonic 150 dispersion was applied to $300 \mathrm{ml}$ of suspension for $14 \mathrm{~min}$, with $5 \mathrm{sec}$ pulses every $9.9 \mathrm{sec}$. The 151 samples remained continuously at cool temperatures to avoid damaging the clay particles with 152 the released heat (Schmidt et al., 1999). The total energy dissipated into the suspension was $c a$. $153200 \mathrm{~J} \mathrm{ml}^{-1}$.

154 The suspensions were allowed to settle according to Stokes' law. After sedimentation, the $\leq 2 \mu \mathrm{m}$ 155 fraction was sampled and centrifuged for 20 minutes at $10,000 \mathrm{rpm}$. The collected $\leq 2 \mu \mathrm{m}$ 156 fraction was then freeze-dried.

\section{$158 \quad 2.3 .{ }^{137} \mathrm{Cs}$ and ${ }^{210} \mathrm{~Pb}$ analysis}

159 The soil was packed into 60-ml pre-tared polyethylene specimen cups and sealed airtight to trap

160 the ${ }^{222} \mathrm{Rn}$ and allow ingrowth of its decay products. The activities of ${ }^{137} \mathrm{Cs}(661.6 \mathrm{keV})$ and ${ }^{210} \mathrm{~Pb}$ 
$161(46.5 \mathrm{keV})$ were determined by gamma spectrometry using the very low-background HPGe 162 detectors available at the Laboratoire des Sciences du Climat et de l'Environnement (LSCE, Gif

163 sur Yvette, France). The ${ }^{210} \mathrm{~Pb}$ (xs) activity was calculated by subtracting the supported activity 164 from the total ${ }^{210} \mathrm{~Pb}$ activity (Evrard et al., 2010).

165 The counting times of the soil samples varied between $8 \times 10^{4}$ and $3 \times 10^{5} \mathrm{~s}$. All measured counts 166 were corrected for background levels, which were measured at least every 2 months, as well as 167 for the detector and geometry efficiencies. The results were systematically expressed in $\mathrm{Bq} \mathrm{kg}^{-1}$. 168 The radionuclide activities were systematically decay-corrected according to the sampling date. 169 The counting efficiencies and quality assurances were conducted using internal and certified 170 IAEA standards that were prepared in the same specimen cups as the samples.

171

172 2.4. Numerical modeling

173

$174 \quad$ 2.4.1. Convection-diffusion equation

175 The migration of fallout radionuclides in soil is classically described using a diffusion176 convection equation (e.g., He and Walling, 1997; Schuller et al., 1997):

178 where $A$ is the total radionuclide activity per volume of soil $\left(\mathrm{Bq} \mathrm{m}^{-3}\right.$; obtained by multiplying the 179 measured activity in $\mathrm{Bq} \mathrm{kg}^{-1}$ by the bulk density of the sample), $z$ is the soil depth (m), $t$ is the 180 time (s), $D_{s}$ is the diffusion coefficient of the solid phase $\left(\mathrm{m}^{2} \mathrm{~s}^{-1}\right), v_{s}$ is the convection velocity $(\mathrm{m}$ $\left.181 \mathrm{~s}^{-1}\right)$, and $\lambda$ is the radioactive decay constant $\left(\mathrm{s}^{-1}\right)$.

182 The diffusion coefficient $D_{s}$ and the convection velocity $v_{\mathrm{s}}$ were assumed as constants with time 183 in this study. Because true velocity coefficients are expected to vary slightly with time (Rosén et 
184 al., 1999), our estimates of $v_{\mathrm{s}}$ (and possibly $D_{s}$ ) represent the weighted average coefficients over 185 the 20 to 50 year period recorded by the two radionuclides. Although these coefficients are 186 generally considered to be constant with depth in the literature (e.g., Smith and Elder, 1999; 187 Bossew and Kirchner, 2004; Schimmack and Feria Márquez, 2006; among others), several 188 authors have proposed that they are depth-dependent; therefore, we tested the use of variable 189 coefficients in a second step (Elzein and Balesdent, 1995; Schuller et al., 2004).

\section{$191 \quad$ 2.4.2. Boundary conditions}

192 A boundary condition of the injection of the radionuclides was applied at the soil surface. The injection of the radionuclides was obtained by multiplying the annual fallout deposition $a_{0}\left(t^{\prime}\right)$ in $\mathrm{Bq} \mathrm{m}^{-2}$ during the considered year $t^{\prime}$ by Dirac delta function $a\left(0, t^{\prime}\right)=a_{0}\left(t^{\prime}\right) \delta\left(t-t^{\prime}\right)$ :

$$
D_{s} \frac{\partial A\left(0, t^{\prime}\right)}{\partial z}=a_{0}\left(t^{\prime}\right) \delta\left(t-t^{\prime}\right)
$$

196 The isotopes were delivered to the surface either annually $\left({ }^{137} \mathrm{Cs}\right)$ or proportionally at every time197 step $\left({ }^{210} \mathrm{~Pb}(\mathrm{xs})\right)$. The input time-series were, therefore, treated as a time-dependent boundary 198 condition: $A\left(0, t^{\prime}\right)=A\left(0, t^{\prime}-1\right)+a_{0}\left(t^{\prime}\right) \delta\left(t-t^{\prime}\right)$.

199 For ${ }^{137} \mathrm{Cs}$, all simulations began in 1954 and finished in the sampling year. The annual global 200 fallout input $a_{G F}\left(t^{\prime}\right)$ followed the distribution calculated by Cambray et al. (1989), with a total 201 fallout accumulation of $3018 \mathrm{~Bq} \mathrm{~m}^{-2}$ by 1986, prior to the Chernobyl accident. The ${ }^{137} \mathrm{Cs}$ input $202\left(a_{C h}\right)$ due to the Chernobyl accident was determined using the empirical equation developed for 203 France (Roussel-Debel et al., 2007). This equation takes into consideration the longitude of the 204 sampling site and the mean cumulative rainfall recorded between the $1^{\text {st }}$ and the $5^{\text {th }}$ of May 1986. 205 The obtained values for the Chernobyl fallout amounted to $661 \mathrm{~Bq} \mathrm{~m}^{-2}$ for Mons, $413 \mathrm{~Bq} \mathrm{~m}^{-2}$ for 
206 Feucherolles and $499 \mathrm{~Bq} \mathrm{~m}^{-2}$ for Boigneville. The Fukushima Dai-ichi accident in 2011 led to 207 negligible ${ }^{137} \mathrm{Cs}$ fallout in France (i.e., $<2 \mathrm{~Bq} \mathrm{~m}^{-2}$; Evrard et al., 2012).

208 For ${ }^{210} \mathrm{~Pb}(\mathrm{xs})$, the annual fallout $\left(a_{P b}\right)$ was considered constant over the last three centuries and 209 was determined using the optimization procedure. In the case of the forest, the simulations were 210 long enough to allow the ${ }^{210} \mathrm{~Pb}$ (xs) to reach dynamic equilibrium between its input and 211 radioactive decay. In the case of the grassland, the simulation began in 1939, with an initial ${ }^{210} \mathrm{~Pb}$ 212 (xs) vertical distribution identical to that recorded in the conventionally tilled plots.

214 The bottom boundary was set deep enough (at $200 \mathrm{~cm}$ ) to avoid influencing the numerical 215 solution within the first $100 \mathrm{~cm}$. We used an advective transport free of diffusion as a boundary 216 condition to avoid spurious accumulations of radionuclides.

\subsubsection{Modeling of mixing by tillage and erosion}

219 Tillage homogenizes the radionuclide concentrations within the tilled horizon. To separate the bioturbation effect from the tillage effect, we modeled tillage at time $t+\Delta t$, where $t$ stands for the time just before the tillage and $\Delta t$ for the time-step, using the following equation:

$$
A(z, t+\Delta t)=\left(1-M_{R}\right) A(z, t)+\frac{M_{R}}{T_{D}} \int_{0}^{T_{D}} A(z, t) d z \quad \forall z \in\left[0 ; T_{D}\right]
$$

223 where $M_{R}$ is the mixing ratio and $T_{D}$ is the tillage depth $(\mathrm{m}) . \mathrm{M}_{\mathrm{R}}$ was set (depending on the tillage

224 practices) to 0.85 for conventional tillage and 0.30 for reduced tillage (according to Ullrich and 225 Volk, 2009); $T_{D}$ ranged between 23 and $28 \mathrm{~cm}$ for conventional tillage and between 5 and $10 \mathrm{~cm}$ 226 for reduced tillage, depending on the history of the tillage practices for a given plot (Table 4). A 227 total erosion term, including water erosion induced by surface runoff and tillage, was included in 228 the modeling for the cropland plots. The erosion and the associated loss of radionuclides was 
229 allowed to occur only in the upper cell of the modeled soil domain, representing the first $0.1 \mathrm{~cm}$ 230 of soil, during the period without vegetal cover (October-February), using the following 231 equation:

$$
A(z, t+\Delta t)=(1-E) A(z, t) \quad \forall z \in[0 ; 0.1]
$$

233 where $E$ is the erosion parameter (in $10^{-3} \mathrm{~cm}$ ). This parameter was adjusted using the fitting

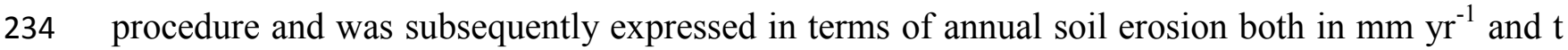

$235 \mathrm{ha}^{-1} \mathrm{yr}^{-1}$ by multiplying the erosion parameter by the number of months with the erosion (five 236 months) and by the surface soil bulk density. Consequently, erosion was determined by both the 237 total inventory and the isotopic concentration at the surface, as well as its evolution with time. 238 Therefore, with low radionuclide concentrations at the surface, substantial erosion would be 239 estimated by the model. The modeling setups and initial parameters for each site are summarized 240 in Table 4.

\subsubsection{Discretization and resolution of the equation}

243 We solved differential equation (1) using upstream finite difference approximations for the 244 spatial derivatives and the semi-implicit Crank-Nicholson scheme as a time-solver. The obtained 245 algebraic system of equations was solved by Gaussian elimination. The time-step was equal to 2460.01 year. The accuracy of the numerical solution was verified by comparing it to the analytical 247 solution with a single pulse-input $a_{0}$ in $\mathrm{Bq} \mathrm{m}^{-2}$ at $t=0$ (5) (e.g., Schuller et al., 1997). The 248 numerical scheme was conservative for the simulations without tillage. The inclusion of annual 249 tillage generated a difference of $0.3 \%$ in the total inventory at the end of the simulation.

$$
A(z, t)=a_{0}\left\{\frac{1}{\sqrt{\pi D_{s} t}} \exp \left(-\frac{\left(z-v_{s} t\right)^{2}}{4 D_{s} t}\right)-\frac{v_{s}}{2 D_{s}} \exp \left(\frac{v_{s} z}{D_{s}}\right) \operatorname{erfc}\left(\frac{v_{s}}{2} \sqrt{\frac{t}{D_{s}}}+\frac{z}{2 \sqrt{D_{s} t}}\right)\right\} \exp ^{-\lambda t}
$$




\subsubsection{Non-linear least squares minimization procedure}

253 The unknown parameters $\left(D_{s}(z), v_{s}(z)\right.$, and $\left.E\right)$ and their standard deviations were determined 254 using a non-linear least squares minimization procedure based on the Levenberg-Marquardt 255 algorithm included in the Python lmfit package. The minimized value for each measurement $A_{m}$ 256 was calculated in integral form to account for the different sampling intervals (Bossew and 257 Kirchner, 2004):

$$
\operatorname{argmin}=\left(A_{m}\left(z_{2}-z_{1}\right)-\int_{z_{1}}^{z_{2}} A(z, t) d z\right)^{2}
$$

259 To estimate the performance of the fitting procedure, we calculated the residual sum of squares $260(R S S)$ for $N$ sampled layers and the modeling efficiency $(E F)$, with $\bar{A}_{m}$ being the mean $A_{m}$ value:

$$
R S S=\sum_{i=0}^{N}\left(A_{m}(i)\left(z_{i 2}-z_{i 1}\right)-\int_{z_{i 1}}^{z_{i 2}} A(z, t) d z\right)^{2}
$$

$$
E F=1-\frac{\sum_{i=0}^{N}\left(A(z, t)-A_{m}(i)\right)^{2}}{\sum_{i=0}^{N}\left(A_{m}(i)-\bar{A}_{m}\right)^{2}}
$$

$E F$ can vary between $-\infty$ and 1 . An $E F$ of 1 is a perfect match between the model and the measurements, whereas a negative $E F$ value means that using the average value of the isotopic concentrations would produce a better representation of the isotopic concentrations than the optimized simulation.

\section{Results and discussion}


271 3.1. Estimation of erosion, lessivage and bioturbation rates based on the ${ }^{137} \mathrm{Cs}$ data

272

273 3.1.1. Inventories and ${ }^{137} \mathrm{Cs}$ depth distributions in bulk soil samples and the $\leq 2 \mu \mathrm{m}$ size

274 fraction

275 The maximum ${ }^{137} \mathrm{Cs}$ inventories were found under the grassland in Mons, the forest in 276 Feucherolles and the conventional tillage in Boigneville (Table 5). Following the estimates of the 277 Chernobyl fallout determined by Roussel-Debel et al. (2007) and the global fallout reported by 278 Cambray et al. (1989), we observed an excellent match between the predictions of the ${ }^{137} \mathrm{Cs}$ 279 deposition for the Mons and Feucherolles sites recalculated for the sampling year (2072 and $2801932 \mathrm{~Bq} \mathrm{~m}^{-2}$, respectively) and for the ${ }^{137} \mathrm{Cs}$ inventories measured in the Mons's grassland and 281 Feucherolles's forest (Table 5). On average, $17 \%$ of the present day ${ }^{137}$ Cs contamination in the 282 studied sites was supplied by the Chernobyl accident, and the rest was due to the nuclear weapon 283 tests.

284 The inventories for the cultivated sites were lower than their natural equivalents (Table 5). 285 Therefore, the cultivated sites were likely affected by soil erosion, which was reflected as a loss 286 of ${ }^{137} \mathrm{Cs}$ compared to the theoretical inventory calculated from the reference sites.

288 In the cases of the grassland and forest, we observed peak-shaped ${ }^{137} \mathrm{Cs}$ vertical distributions 289 with maximum isotopic concentrations in the A horizon (Fig. 1). The depths of maximum 290 isotopic concentrations were $11 \mathrm{~cm}$ in the grassland and $13 \mathrm{~cm}$ in the forest. The vertical 291 distributions in the cropland remained roughly homogeneous in the tillage horizon. In the cases 292 of manure input and both reduced tillage plots, we observed the maximum below the tillage 293 depth. The no tillage experiment showed two barely distinguishable maxima at $5 \mathrm{~cm}$ and $13 \mathrm{~cm}$. 
295 The deepest ${ }^{137} \mathrm{Cs}$ penetration could be differentiated between the undisturbed and cultivated 296 sites. Under permanent vegetation, ${ }^{137} \mathrm{Cs}$ penetration was due to pedological processes. The 297 penetration reached $50 \mathrm{~cm}$ depth in the grassland and $40 \mathrm{~cm}$ depth in the forest. In the 298 agricultural sites, this penetration was controlled by the tillage depth after the main ${ }^{137}$ Cs input, 299 as displayed by the sharp gradient in concentration at the lower limit of the tillage layer. In 300 Feucherolles, this depth corresponded to $40 \mathrm{~cm}$, whereas it reached $37 \mathrm{~cm}$ in Mons, independent 301 of the different treatments. Additionally, in Boigneville, the depth of ${ }^{137}$ Cs penetration varied 302 slightly depending on the tillage practice, as described in the following sequence: conventional 303 tillage $(35 \mathrm{~cm})>$ reduced tillage $(31 \mathrm{~cm})>$ no tillage $(30 \mathrm{~cm})$. The mass balance calculation 304 showed that there was a similar amount of soil within the upper $35 \mathrm{~cm}$ under the conventional 305 tillage sites, within the upper $31 \mathrm{~cm}$ under the reduced tillage sites and the upper $30 \mathrm{~cm}$ under the 306 no tillage sites. This may be interpreted as a result of soil compaction due to tillage reduction, 307 and this phenomenon has already been described by Dimassi et al. (2013). Therefore, the 308 maximum penetration depth under agricultural sites was related to the maximum tillage depth 309 before the start of the long-term experiment but after the majority of the ${ }^{137} \mathrm{Cs}$ was supplied by 310 global fallout.

312 We measured the ${ }^{137} \mathrm{Cs}$ activities in the $\leq 2 \mu \mathrm{m}$ size fractions for a selection of 25 samples. Using 313 the data for particle-size distributions, we calculated the contribution of the ${ }^{137}$ Cs activity borne 314 by the $\leq 2 \mu \mathrm{m}$ fraction to the bulk sample activity (Table 6 ). This contribution was, on average, $31587 \pm 10 \%$ in Mons, $94 \pm 6 \%$ in Feucherolles and $95 \pm 10 \%$ in Boigneville. Therefore, we 316 conclude that ${ }^{137} \mathrm{Cs}$ is predominantly associated with the $\leq 2 \mu \mathrm{m}$ size fraction in the soils of the 
317 studied sites and confirm that ${ }^{137} \mathrm{Cs}$ effectively tracks the transfers of this particle size fraction 318 within the soil profile.

\subsubsection{Modeling of ${ }^{137} \mathrm{Cs}$ vertical distributions with constant coefficients}

321 In the grassland, forest and no tillage experiments, the diffusion coefficients were relatively high

322 (Table 7), and diffusion was the main mixing process. For the cultivated plots (with the exception of the no till experiment), however, we obtained diffusion coefficients lower than 0.01

$\mathrm{cm}^{2} \mathrm{yr}^{-1}$. We conclude that both conventional and reduced tillage induced such a large degree of mixing that diffusion was masked in the isotopic distribution profiles and that the model was thus unable to determine the respective contributions of the two processes. Therefore, the

327 cultivated plots were modeled without diffusion. These simulations performed well (Table 7), 328 yielding EFs ranging between 0.97 and 0.99 and a good fit to the data below the tillage depths.

329 The convection rates in all plots ranged from 0.08 to $0.29 \mathrm{~cm} \mathrm{yr}^{-1}$, with a mean value of 0.16 $330 \mathrm{~cm} \mathrm{yr}^{-1}$ (Table 7). The highest $v_{s}$ coefficient was observed under the grassland sample $(0.29 \pm$ $0.02 \mathrm{~cm} \mathrm{yr}^{-1}$ ). Similar convection velocities, varying between 0.15 and $0.28 \mathrm{~cm} \mathrm{yr}^{-1}$ (a mean of $0.21 \pm 0.05 \mathrm{~cm} \mathrm{yr}^{-1}$ ), were obtained for grassland Luvisols in Bavaria (Schimmack and Feria Márquez, 2006). For the sites under cultivation, the $v_{s}$ coefficients were higher in Boigneville 334 than in the two other sites; the $v_{s}$ decreased with tillage in Boigneville but not in Mons, which experienced a shorter duration of tillage reduction. Additionally, the $v_{s}$ increased with manure 336 input. The $v_{s}$ coefficients were similar between the forest and conventional tillage plots. For the 337 forest site, the obtained $E F$ was rather poor $(E F=0.78)$, and the model clearly underestimated the the impact of variable coefficients with depth. 
$341 \quad$ 3.1.3 Modeling of ${ }^{137} \mathrm{Cs}$ vertical distributions with variable coefficients

342 We successively tested the following scenarios: i) exponentially decreasing the diffusion

343 coefficient and ii) changing the convection velocity based on segments lines with endpoints at 344 characteristic depths.

Exponential decrease in the diffusion and constant velocity for the grassland, forest and the no

347 till experiments

348 The mixing in soils described by the diffusion equation is classically interpreted as 349 corresponding to the bioturbation activity (e.g., Elzein and Balesdent, 1995; Schiffers et al., 350 2011). Bioturbation depends on organic matter distribution, which is consumed by bioturbating 351 organisms. Therefore, we decided to model the evolution of the diffusion coefficient with depth 352 as the evolution of organic matter, which decreases exponentially with depth. We considered an 353 exponential evolution for $D_{s}(z)=D_{0} \exp (-b z)$, with the parameters $D_{0}$ and $b$ to be optimized during 354 the fitting procedure.

355 The modeling efficiency $E F$ for the models with exponentially decreasing diffusion improved 356 from 0.96 to 0.97 for grassland, from 0.78 to 0.87 for forest and from 0.80 to 0.95 for the no till 357 samples compared to the models with a single value for diffusion (Table 7). For the forest site, 358 the diffusion coefficient was high at the surface and rapidly decreased with depth, becoming 359 insignificant below $20 \mathrm{~cm}$ (Table 7). For the grassland, the diffusion was lower than that of the 360 forest at the surface, but it slowly decreased with depth, approaching zero only below $80 \mathrm{~cm}$.

361 We calculated the mean diffusion in the first $30 \mathrm{~cm}$, and the results were as follows: $4.78 \pm 12.39$ $362 \mathrm{~cm}^{2} \mathrm{yr}^{-1}$ under forest; $3.16 \pm 1.92 \mathrm{~cm}^{2} \mathrm{yr}^{-1}$ under grassland and $3.33 \pm 7.73 \times 10^{-5} \mathrm{~cm}^{2} \mathrm{yr}^{-1}$ under 
363 the no till plot. These values and the associated uncertainties remained similar to the values

364 found when using the constant diffusion model (Fig. 3). For the no till experiment, the mean

365 diffusion remained unreasonably low, inducing a very narrow peak at $3 \mathrm{~cm}$ depth in the ${ }^{137} \mathrm{Cs}$

366 depth distribution (Fig. 1). A potential explanation for the difficulty in quantifying the diffusion

367 in this plot might be that some ${ }^{137} \mathrm{Cs}$ had already been substantially redistributed by tillage before

368 1970. However, the low diffusion in the no till treatment is in accordance with the very sharp

369 carbon gradient that was developed and maintained in the upper $10 \mathrm{~cm}$ throughout the 41 years

370 of treatment at Boigneville (Fig. 2).

371

372 Variable diffusion and variable convection velocity

373 Because organic matter stabilizes clay particles (Chenu et al., 2000), we considered that it most

374 likely decreases the convection velocity. Similarly, we assumed that $\mathrm{pH}$ influenced this velocity 375 and, therefore, that the convection velocity varied with depth as a function of these two 376 pedologic characteristics of the soil (Fig. 2). The effects of $\mathrm{pH}$ variations on the convection 377 velocity were considered using the $\mathrm{IMC}_{\mathrm{pH}}$ indicator defined by Van Breemen and Buurman 378 (2002), which varies between 0 and 1, where 1 indicates likely clay migration, and 0 indicates 379 low probability of migration. We estimated that the organic matter content controlled convection 380 velocity between 0 and $20 \mathrm{~cm}$, within the depth range where the $\mathrm{IMC}_{\mathrm{pH}}$ generally had a value of 3811 (Fig. 2). In the case of conventional tillage, where the organic matter content was low, we 382 hypothesized that the $\mathrm{IMC}_{\mathrm{pH}}$ would more likely impact the evolution of convection velocity, with 383 changes occurring below $40 \mathrm{~cm}$ depth in Mons and Feucherolles and below $20 \mathrm{~cm}$ in 384 Boigneville. The transition zones of these parameters were chosen as the endpoints of the 385 segment lines for modeling simplicity (Table 4). 

401 depth.

402 Finally, despite the important uncertainties, the simulation of the concentrations below $25 \mathrm{~cm}$ 403 depth improved with the variable velocity parameters, justifying the use of such parameters. 404 The mean velocity in the first $40 \mathrm{~cm}$ had much higher uncertainties with the variable velocities 405 406 ( $276 \%$ on average) than with the constant velocities ( $8 \%$ in average) (Fig. 3), principally due to error propagation. In the cultivated areas, the mean convection velocity of depths greater than 40

Compared to the model with constant convection velocity, the modeling efficiency $E F$ improved at most sites, although three sites already had an $E F$ value of 0.99 (Table 8).

The calculated averages of variable diffusion parameters were not significantly different from the ones found for the constant convection velocity models (Fig. 3). In the no till experiment, diffusion was still very low.

The obtained convection velocities increased under conventional tillage (manure input included) and in the grassland for the $0-20 \mathrm{~cm}$ and $0-40 \mathrm{~cm}$ zones, respectively. At $40 \mathrm{~cm}$ depth, the convection velocity ranged between 0.16 and $0.29 \mathrm{~cm} \mathrm{yr}^{-1}$ for conventional tillage, while it decreased for the grassland.

For the reduced tillage in Mons and the Feucherolles forest, the convection velocity decreased in the $0-20 \mathrm{~cm}$ range, followed by a slight increase in the $20-40 \mathrm{~cm}$ range in Mons under reduced tillage; however, there was a sharp increase in the 20-40 cm range in the forest of Feucherolles. The convection velocity at the surface under reduced tillage was significantly higher $\left(v_{s}=0.23 \pm\right.$ $0.05 \mathrm{~cm} \mathrm{yr}^{-1}$ ) than that under conventional tillage in Mons. In contrast, in the reduced tillage experiments (including no tillage) in Boigneville, the convection velocity did not change with

407 408 cm was not significantly different between the constant and variable parameters. In the grassland and forest, however, the mean variable convection velocities in the first $40 \mathrm{~cm}$ were larger with 
409 the convection velocities that varied by depth than with the constant convection velocities

410 (Tables 7 and 8). The uncertainties associated with the variable convection model for these sites

411 were among the most important.

\section{$413 \quad 3.1 .4$. Erosion rates}

414 Simulated and calculated erosion did not significantly change between the constant and variable 415 convection velocities and ranged between 1.81 to $9.80 \mathrm{t} \mathrm{ha}^{-1} \mathrm{yr}^{-1}$ (Fig. 3).

416 The erosion rates decreased from Mons to Feucherolles to Boigneville. The tillage reduction, as 417 well as manure input, lowered the erosion rate, notably in Mons. These trends are in agreement 418 with the literature, and the global erosion rates were consistent with ones reported for Western 419 Europe, such as ca. 1-5 $\mathrm{t} \mathrm{ha}^{-1} \mathrm{yr}^{-1}$ for erosion due to runoff (Cerdan et al., 2010) and $3.3 \mathrm{t} \mathrm{ha}^{-1} \mathrm{yr}^{-1}$ 420 due to tillage erosion (Van Oost et al., 2009). The highest erosion rates, which were obtained in 421 Mons, might be related to the inclusion of sugar beet cultivation in the crop rotation, which 422 enhances runoff and erosion (Evrard et al., 2008). Furthermore, sugar beet harvest is known to 423 export significant quantities of soil (Poesen et al., 2001).

\subsection{Validation of the diffusion and convection velocity coefficients with the ${ }^{210} \mathrm{~Pb}(\mathrm{xs})$ data}

429 The ${ }^{210} \mathrm{~Pb}(\mathrm{xs})$ activities were larger than the limit of quantification only in 29 of the 113 samples 430 (Supplementary data file). In all other samples (84 of the 113), we could not discern any 431 significant activity of ${ }^{210} \mathrm{~Pb}(\mathrm{xs})$ due to very small differences between the total and supported 
$432{ }^{210} \mathrm{~Pb}(\mathrm{xs})\left(\sim 3 \mathrm{~Bq} \mathrm{~kg}{ }^{1}\right)$. Despite these high uncertainties, we observed some general trends in the 433 vertical ${ }^{210} \mathrm{~Pb}$ (xs) distributions. The ${ }^{210} \mathrm{~Pb}$ (xs) concentrations were detected down to $20 \mathrm{~cm}$ in 434 the grassland, with a total inventory of $1548 \pm 1377 \mathrm{~Bq} \mathrm{~m}^{-2}$. Higher concentrations were 435 measured in the forest, and the radionuclide was detected down to a depth of $14 \mathrm{~cm}$, with a total 436 inventory of $1921 \pm 1959 \mathrm{~Bq} \mathrm{~m}^{-2}$. The maximum isotopic concentrations of ${ }^{210} \mathrm{~Pb}(\mathrm{xs})$ were 437 found at the soil surface, with the exception of the manure plot, where the maximum 438 concentrations were measured at $20 \mathrm{~cm}$. The three plots under conventional tillage displayed $439{ }^{210} \mathrm{~Pb}(\mathrm{xs})$ concentrations below the detection limit at all depths due to dilution generated by the 440 tillage. Under reduced tillage, the ${ }^{210} \mathrm{~Pb}(\mathrm{xs})$ concentrations were detected only in the upper 10 $441 \mathrm{~cm}$ and only in the upper $4 \mathrm{~cm}$ in the no till experiment. Because of the larger uncertainties 442 associated with the ${ }^{210} \mathrm{~Pb}(\mathrm{xs})$ data, we decided to test whether the $D_{s}$ and $v_{s}$ values determined by 443 the ${ }^{137} \mathrm{Cs}$ vertical distributions would fit the ${ }^{210} \mathrm{~Pb}(\mathrm{xs})$ data only for the grassland and the forest.

445 Isotopic concentrations of ${ }^{210} \mathrm{~Pb}(\mathrm{xs})$ in the $\leq 2 \mu \mathrm{m}$ size fraction were detected in 19 of the 25

446 samples (Table 6). For 8 samples collected below $4 \mathrm{~cm}$ depth, ${ }^{210} \mathrm{~Pb}(\mathrm{xs})$ was detected in the $\leq 2$ $447 \mu \mathrm{m}$ size fractions, even though concentrations remained below the detection limits in the bulk 448 soil samples. The ${ }^{210} \mathrm{~Pb}$ (xs) concentrations in the $\leq 2 \mu \mathrm{m}$ size fraction, relative to the bulk 449 samples, were $65 \pm 14 \%$ on average for the surface samples (range from 0 to $4 \mathrm{~cm} \mathrm{n=7)} \mathrm{and} 129$ $450 \pm 16 \%$ on average for the deeper samples $(n=4)$. Therefore, we conclude that, in the surface 451 samples $(0-4 \mathrm{~cm})$, a portion of the ${ }^{210} \mathrm{~Pb}(\mathrm{xs})$ was sorbed by particles coarser than $2 \mu \mathrm{m}$, but at 452 deeper levels, the ${ }^{210} \mathrm{~Pb}$ (xs) was predominantly associated with the $\leq 2 \mu \mathrm{m}$ size fraction. The $453{ }^{210} \mathrm{~Pb}(\mathrm{xs})$ content of the size fraction coarser than $2 \mu \mathrm{m}$ linearly increased with increases in the 454 organic carbon content of this fraction (Fig. 4). This observation suggests that the ${ }^{210} \mathrm{~Pb}(\mathrm{xs})$ that 
455 was not contained in the $\leq 2 \mu \mathrm{m}$ fraction may be linked to coarse organic matter particles. This

456 corroborates the conclusions of Dörr and Münnich (1989), suggesting that organic matter

457 controls the migration of ${ }^{210} \mathrm{~Pb}(\mathrm{xs})$ in the soil.

458

459

\subsubsection{Modeling of ${ }^{210} \mathrm{~Pb}$ (xs) vertical distributions and its signification}

460 The fitting of the ${ }^{210} \mathrm{~Pb}(\mathrm{xs})$ depth distribution estimated a flux of ${ }^{210} \mathrm{~Pb}(\mathrm{xs})$ of $93 \pm 8 \mathrm{~Bq} \mathrm{~m}^{-2} \mathrm{yr}^{-1}$

461 for the grassland and $83 \pm 18 \mathrm{~Bq} \mathrm{~m}^{-2} \mathrm{yr}^{-1}$ for the forest site, which is similar to the estimation of 462 the mean ${ }^{210} \mathrm{~Pb}$ flux of $117 \mathrm{~Bq} \mathrm{~m}^{-2} \mathrm{yr}^{-1}$ over continents in the $30^{\circ}-60^{\circ} \mathrm{N}$ latitudinal band (Preiss et 463 al., 1996). However, the simulations fit the data poorly, as shown by the low modeling 464 efficiencies $(E F)$ (lower than 0.5 for all land uses considered). The variable velocity model failed 465 to reproduce the surface peak of the forest plot, though the simulation with constant velocity 466 performed better (Fig. 5). As discussed above, a portion of the ${ }^{210} \mathrm{~Pb}(\mathrm{xs})$ in this layer is bound to 467 organic matter particles larger than $2 \mu \mathrm{m}$ that were most likely not transferred by lessivage. We 468 therefore conclude that ${ }^{210} \mathrm{~Pb}(\mathrm{xs})$ in the bulk soil might not be a suitable tracer for lessivage. We 469 modeled the ${ }^{210} \mathrm{~Pb}(\mathrm{xs})$ activities measured in the $\leq 2 \mu \mathrm{m}$ size fractions for the forest. In that case, 470 the simulation with variable convection velocity was more satisfactory, with an $E F$ improving 471 from -0.02 to 0.67 . Due to the low number of samples and the poor modeling efficiency, we 472 conclude that the depth distribution of ${ }^{210} \mathrm{~Pb}$ does not invalidate the parameters of solid matter 473 transfer that were calculated from the ${ }^{137} \mathrm{Cs}$ profiles.

474

475 3.3. Estimation of bioturbation and modern lessivage rates with radionuclides: 476 contribution and limitations 

vegetation and cultivated sites

Bioturbation is generally addressed as the amount of matter ingested by macrofauna (mainly the earthworm in temperate climates) per year in the uppermost $30 \mathrm{~cm}$ of the soil (Gobat et al., 2004). To express the diffusion in terms of bioturbation, we followed the approach described by 483 Jarvis et al. (2010), who described the relationship between diffusion and the ingestion rate, 484 taking into account the soil bulk density and the body length of earthworms. In our case, we estimated the earthworm ingestion rates over the first $30 \mathrm{~cm}$ of the soil from the mean diffusion over the same depth (calculated with depth dependent variable diffusion) and the body length of earthworms ( 8 to $10 \mathrm{~cm}$ for sites with permanent vegetation and $5 \mathrm{~cm}$ length for no till experiment plot). Because of important uncertainties associated to the surface diffusion term for the forest, the bioturbation was not evaluated for this plot. For the no till experiment plot, we used the value found with constant diffusion $\left(0.13 \mathrm{~cm}^{2} \mathrm{yr}^{-1}\right)$ because the value obtained with the variable coefficient was considered too low. For body lengths of $10 \mathrm{~cm}$ and $8 \mathrm{~cm}$, we obtained 492 ingestion rates of 147 and $229 \mathrm{~kg} \mathrm{~m}^{-3} \mathrm{yr}^{-1}$ and soil turnover rates of 0.11 and $0.17 \mathrm{yr}^{-1}$, 493 respectively, for the grassland. For the no till experiment, the ingestion rate was $59 \mathrm{~kg} \mathrm{~m}^{-3} \mathrm{yr}^{-1}$, 494 with a soil turnover rate of $0.04 \mathrm{yr}^{-1}$. By integrating the ingestion rates over the upper $30 \mathrm{~cm}$, we 495 calculated the associated mean bioturbation of this layer to be 441 and $687 \mathrm{tha}^{-1} \mathrm{yr}^{-1}$ for the 496 grassland and $177 \mathrm{t} \mathrm{ha}^{-1} \mathrm{yr}^{-1}$ for the no till experiment. The latter result is remarkably consistent 497 with the value of $126 \mathrm{t} \mathrm{ha}^{-1} \mathrm{yr}^{-1}$ estimated by the ecological studies of earthworm biomass at the 498 studied site (Cluzeau, pers. communication). Unfortunately, we did not benefit from similar studies for our grassland and forest sites. Therefore, we summarized the estimates of bioturbation 500 and surface cast rates for grasslands and deciduous forests in humid temperate climates from the 
501 literature (Table 9). The range of bioturbation rates is extremely large, especially in grasslands.

502 Our results are the same order of magnitude as published results for grasslands. Obviously, 503 inferring solid matter transport rates from earthworm ingestion rates would be improved by 504 estimating the average distance of soil transport by the organisms, which depends on their 505 ecological categories (i.e., anecic, epianecic or endogeic). Some bioturbation processes may also 506 lead to convection-like transport. Litter or A horizon incorporation into deep layers by anecic 507 earthworms or downward movement via vertical galleries or root holes may transport topsoil 508 downwards. Reciprocally, the deposition of deep horizon matter at the surface as casts, such as 509 that performed by anecic earthworms or termites, may help bury the A horizons, a process which 510 would contribute to a uniform downwards movement of the intermediate layers. Thus, the mean 511 velocity over the $0-40 \mathrm{~cm}$ layer in the forest and grassland soils (approximately $0.5 \mathrm{~cm} \mathrm{yr}^{-1}$; 512 Table 8) may represent a quantitative estimate of such biological "burial" activity.

513 Finally, while tillage homogenizes the isotopic concentrations within the tilled horizon, it creates 514 an important concentration gradient at the lower boundary of this layer that allows the 515 investigation of the local transfer rates at this depth. Because the implementation of the diffusion 516 process was not necessary for modeling conventional and reduced tillage, we conclude that the 517 diffusion process is negligible below the depth of conventional tillage $(25-28 \mathrm{~cm})$ during the

518 investigated timescale. At this depth, the diffusion was of $\sim 1.99 \mathrm{~cm}^{2} \mathrm{yr}^{-1}$ for the grassland, but 519 was negligible for the forest.

520

$521 \quad 3.3 .2$. Impacts of pedologic characteristics on modern lessivage

522 Because ${ }^{137} \mathrm{Cs}$ and ${ }^{210} \mathrm{~Pb}(\mathrm{xs})$ are mainly sorbed on the fraction $\leq 2 \mu \mathrm{m}$, their transfer in the soil 523 by convection may represent the lessivage of fine particles. These isotopes are mainly present in 
524 the A horizons, and they effectively trace the particle transport from the A to the E horizons (i.e.,

525 eluviation). According to the simulations with the depth-dependent variable coefficient, lessivage

526 is more active in the grassland and the forest than in areas under cultivation (higher $v_{s}$, Fig. 3),

527 which is consistent with their high $\mathrm{IMC}_{\mathrm{pH}}$ (equal to 1) over the upper $40 \mathrm{~cm}$. For areas under

528 cultivation, this indicator is either lower than 1 or equal to 1 at a maximum depth of $20 \mathrm{~cm}$.

529 Reducing tillage did not influence lessivage in Mons, but it did reduce lessivage in Boigneville.

530 Because Mons only experienced 11 years of tillage reduction while Boigneville experienced 42

531 years, the apparent difference in the action of tillage reduction on lessivage may be due to the

532 difference in duration. The slowing of lessivage when tillage is reduced is consistent with the

533 increase in structural stabilization observed when the tillage intensity decreases (Le Bissonnais

534 and Arrouays, 1997).

535 To compare these convection velocities to the concentrations of particles migrating through soils

536 measured in a column experiment in the literature (see synthesis by Quénard et al., 2011), we

537 calculated the annual flux of particles $\left(f\right.$ in $\left.\mathrm{g} \mathrm{cm}^{-2} \mathrm{yr}^{-1}\right)$ over the upper $40 \mathrm{~cm}$ for the grassland,

538 and we divided it by the annual drainage (estimated as the difference between annual rainfall and

539 the potential evapotranspiration).

540 The annual flux of particles was estimated using the following equation:

$541 f(z)=v_{s}(z) a_{D}(z)$

542 where $v_{s}$ is the convection velocity estimated from the ${ }^{137} \mathrm{Cs}$ data (Table 8) and $a_{D}$ is the quantity 543 of available $\leq 2 \mu \mathrm{m}$ fraction (in $\mathrm{g} \mathrm{cm}^{-3}$ ) for particle transfer at a given depth, which is calculated 544 as follows:

$545 \mathrm{a}_{\mathrm{D}}=\rho d C_{<2 \mu m}$ 
546 where $\rho$ is the bulk soil density $\left(\mathrm{g} \mathrm{cm}^{-3}\right.$ Table 3$), C_{<2 \mu m}$ is the $\leq 2 \mu \mathrm{m}$ particle-size fraction $\left(\mathrm{g} \mathrm{g}^{-1}\right.$,

547 Table 3 ) and $d$ is the fraction of the $\leq 2 \mu \mathrm{m}$ size fraction surrounding the macropores (considered

548 available for particle transfer). Based on the hydraulic properties determined for this soil (data

549 not shown) and by defining macropores either as pores larger than $150 \mu \mathrm{m}$ or as pores larger than

$5508 \mu \mathrm{m}$, we estimated that the macroporosity of this soil corresponds either to $1 \%$ or $22 \%$ of the

551 total porosity, depending on the assumed threshold. The relative abundance of the $\leq 2 \mu \mathrm{m}$

552 particles surrounding the macropores was considered to be proportional to the relative abundance

553 of the macropores, as proposed by Finke (2012). The obtained flux of particles ranged from

$5540.57 \times 10^{-3}$ to $12.8 \times 10^{-3} \mathrm{~g} \mathrm{~cm}^{-2} \mathrm{yr}^{-1}$. The average drainage calculated for this site for the last 30

555 years, based on data provided by Meteo France (Safran grid), was $103 \mathrm{~mm} \mathrm{yr}^{-1}$. Therefore, we

556 estimated that the obtained convection velocity corresponds to concentrations of the $\leq 2 \mu \mathrm{m}$

557 particles in the soil water ranging from 0.06 to $1.24 \mathrm{~g} \mathrm{~L}^{-1}$. These concentrations are of the same

558 order of magnitude as the concentrations measured in the soil column experiments performed by

559 Jacobsen et al. (1997), Kjaergaard et al. (2004) and Cornu et al. (2014).

560

561 5. Conclusions

562

563 We investigated the vertical distribution of two fallout radionuclides $\left({ }^{137} \mathrm{Cs}\right.$ and $\left.{ }^{210} \mathrm{~Pb}(\mathrm{xs})\right)$ in 9 564 Luvisol profiles from northern France to determine the impact of variable organic matter content, $565 \mathrm{pH}$ and farming practices on the vertical transfer of solid matter in the soils, particularly by 566 bioturbation and lessivage. The ${ }^{137}$ Cs mass balance calculations showed that as much as $91 \pm 9$ $567 \%$ of the ${ }^{137} \mathrm{Cs}$ was linked to the $\leq 2 \mu \mathrm{m}$ size fraction, thus implying that ${ }^{137} \mathrm{Cs}$ is a valid tracer for 568 quantifying solid matter transfers in these soils. To model these processes, bioturbation was 
569 estimated by calculating diffusion coefficients and lessivage was quantified by calculating 570 convection velocity coefficients. In the model, both coefficients were considered either as

571 constant or variable with depth. Tillage was represented by a mixing equation, and we added a

572 soil erosion term to fit with the measured inventories. The simulations greatly improved when

573 the variable coefficients were used, especially for the forest. Our modeling attempts showed that

574 diffusion could not be quantified when tillage was implemented, thereby demonstrating that the

575 large impact of tillage overshadows diffusion. We showed that the diffusion, and therefore

576 bioturbation, was negligible below the tillage depth in the cultivated sites, below $20 \mathrm{~cm}$ in the

577 forest and $80 \mathrm{~cm}$ in the grassland. The measured diffusion coefficients, when converted to

578 earthworm ingestion rates for the upper $30 \mathrm{~cm}$, corresponded to 441 and $687 \mathrm{t} \mathrm{ha}^{-1} \mathrm{yr}^{-1}$ for the

579 grassland. The mean convection velocities in the upper $40 \mathrm{~cm}$ ranged between 0.06 and 0.59

$580 \mathrm{~cm} \mathrm{yr}^{-1}$ and varied according to the following decreasing sequence: forest $=$ grassland $>$

581 conventional tillage $>$ reduced tillage $=$ no tillage. However, it is important to note that we traced

582 the release of particles from the surface (eluviation) rather than their accumulation (illuviation).

583 The transfer coefficients obtained using the ${ }^{137} \mathrm{Cs}$ data were applied to the ${ }^{210} \mathrm{~Pb}(\mathrm{xs})$ distributions

584 in the second step. The simulations performed only moderately well, and the surface

585 concentrations in the forest were underestimated by the model with the variable coefficients.

586 These results improved when the concentrations of ${ }^{210} \mathrm{~Pb}(\mathrm{xs})$ of the $\leq 2 \mu \mathrm{m}$ size fraction were

587 simulated, rather than that of the bulk soil, as a portion of the ${ }^{210} \mathrm{~Pb}(\mathrm{xs})$ was adsorbed on the

588 organic particles $>2 \mu \mathrm{m}$ at the soil surface.

589 The isotopes ${ }^{137} \mathrm{Cs}$ and ${ }^{210} \mathrm{~Pb}(\mathrm{xs})$ are only relevant to trace the transfer of particles in the A 590 horizon over short periods of time (several tens of years). Therefore, the estimated velocities may 591 not be directly extrapolated to the entire soil profile. To explore the kinetics of vertical matter 
592 transfers in deeper horizons, other tracers with a stronger affinity for clay and longer half-lives

593 (e.g., ${ }^{241} \mathrm{Am}$ or meteoric ${ }^{10} \mathrm{Be}$ ) could be measured.

595 Acknowledgements:

596 This research was conducted in the framework of the Agriped project (ANR-10-BLANC-605),

597 which is supported by the French National Research Agency (ANR), and M. Jagercikova, who 598 received a PhD grant from the French National Institute for Agricultural Research (INRA).

599 The authors are grateful to Dr. Frédéric Golay, Dr. Cédric Galusinski and Dr. Gloria Faccanoni 600 for their suggestions regarding numerical modeling; to Monique Mayor and Fréderic Haurine for 601 their contributions to the sample preparations; to Patrick Signoret for the carbon analyses; to Dr.

602 Bruno Mary, Dr. David Montagne and Nicolas Brunet for providing the soil bulk density data; to 603 the Agriped team for contributing to the sampling; to INRA of Mons en Chaussée, Grignon and 604 Arvalis for providing access to their long-term experimental site and its associated data; and to 605 Meteo France for providing climatic data from the Safran Grid for the studied sites.

606

607 References

608 Anderson, J. M., 1988. Invertebrate-mediated transport processes in soils. Agric. Ecosyst. $609 \quad$ Environ. $24(1), 5-19$.

610 Antoine, P., Catt, J., Lautridou, J. P., Sommé, J., 2003. The loess and coversands of northern 611 France and southern England. J. Quat. Sci. 18 (3- 4), 309-318.

612 Barnett, C. M., Bengough, A. G., McKenzie, B. M., 2009. Quantitative image analysis of 613 earthworm-mediated soil displacement. Biology and Fertility of Soils, 45(8), 821-828. 
614 615

616 617

618

619

620

621

622

623

624

625

626

627

628

629

630

631

632

633

634

635

636

Bieri, M., Cuendet, G., 1989. Die Regenwürmer, eine wichtige Komponente von Ökosystemen. Schweiz. Landw. Fo, 28 (2) 81-96.

Bockheim, J., Gennadiyev, A., 2000. The role of soil-forming processes in the definition of taxa in Soil Taxonomy and the World Soil Reference Base. Geoderma 95 (1-2), 53-72.

Bossew, P., Kirchner, G., 2004. Modelling the vertical distribution of radionuclides in soil. Part 1: the convection-dispersion equation revisited. J. Environ. Radioact. 73 (2), 127-150.

Bouché, M. B., 1981. Contribution des lombriciens aux migrations d'éléments dans les sols tempérés. Colloques Internationaux du Centre National de la Recherche Scientifique, No. 303, pp. 145-53.

Bouché, M.B., 1982. Ecosystème prairial. 4.3 Un exemple d'activité animale: le rôle des lombriciens. Acta Oecol. Oecol. Gen. 3, 127-154.

Boudreau, B. P., 1986. Mathematics of tracer mixing in sediments; I, Spatially-dependent, diffusive mixing. Am. J. Sci., 286 (3), 161-198.

Cambray, R. S., Playford, K., Lewis, G., Carpenter, R., 1989. Radioactive fallout in air and rain: results to the end of 1988. Environmental and Medical Sciences Division, United Kingdom Atomic Energy Authority.

Cerdan, O., Govers, G., Le Bissonnais, Y., Van Oost, K., Poesen, J., Saby, N., Gobin, A., Vacca, A., Quinton, J., Auerswald, K., Klik, A., Kwaad, F.J.P.M., Raclot, D., Ionita, I., Rejman, J., Rousseva, S., Muxart, T., Roxo, M.J., Dostal, T., 2010. Rates and spatial variations of soil erosion in Europe: A study based on erosion plot data. Geomorphology 122 (1), 167177.

Chenu, C., Le Bissonnais, Y., Arrouays, D., 2000. Organic matter influence on clay wettability and soil aggregate stability. Soil Sci. Soc. Am. J. 64 (4), 1479-1486. 
637 Cornu, S., Quénard, L., Cousin, I., Samouëlian, A., 2014. Experimental approach of lessivage:

638

639

640

641

642

643

644

645

646

647

648

649

650

651

652

653

654

655

656

657

658

659

quantification and mechanisms. Geoderma 213, 357-370.

Cremers, A., Elsen, A., Depreter, P., Maes, A., 1988. Quantitative-analysis of radiocesium retention in soils. Nature 335 (6187), 247-249.

Darwin, C., 1881. The formation of vegetable mould through the action of worms, with observations on their habits. John Murray, London. 326 pp.

Dexter, A.R., 1993. Heterogeneity of unstaturated, gravitional flow of water through beds of large particles. Water Resour. Res. 29 (6), 1859-1862.

Dimassi, B., Cohan, J. P., Labreuche, J., Mary, B., 2013. Changes in soil carbon and nitrogen following tillage conversion in a long-term experiment in Northern France. Agric., Ecosyst. Environ. 169, 12-20.

Dörr, H., Münnich, K., 1989. Downward movement of soil organic-matter and its influence on trace-element transport (Pb-210, Cs-137) in the soil. Radiocarbon 31 (3), 655-663, 13th International Radiocarbon conf, Dubrovnik, Yugoslavia, Jun 20- 25, 1988.

Edwards, C. A., Lofty, J. R., 1977. Biology of Earthworms, 2nd edn. Chapman and Hall, London.

Elzein, A., Balesdent, J., 1995. Mechanistic simulation of vertical distribution of carbon concentrations and residence times in soils. Soil Sci. Soc. Am. J. 59 (5), 1328-1335.

Evrard, O., Vandaele, K., Bielders, C.L., van Wesemael, B., 2008. Seasonal evolution of runoff generation on agricultural land in the Belgian loess belt and implications for muddy flood triggering. Earth Surf. Process. Landforms 33 (8), 1285-1301.

Evrard, O., Némery, J., Gratiot, N., Duvert, C., Ayrault, S., Lefèvre, I., Poulenard, J., Prat, C., Bonté, P., Esteves, M., 2010. Sediment dynamics during the rainy season in tropical 
highland catchments of central Mexico using fallout radionuclides. Geomorphology 124, 42-54.

Evrard, O., Van Beek, P., Gateuille, D., Pont, V., Lefèvre, I., Lansard, B., Bonté, P., 2012. Evidence of the radioactive fallout in France due to the Fukushima nuclear accident. J. Environ. Radioact. 114, 54-60.

Fedoroff, N., 1997. Clay illuviation in Red Mediterranean soils. Catena, 28, 171-189.

Finke, P. A., 2012. Modeling the genesis of Luvisols as a function of topographic position in loess parent material. Quat. Int. 265, 3-17.

Finke, P. A., Hutson, J. L., 2008. Modelling soil genesis in calcareous loess. Geoderma 145 (3), 462-479.

Gobat, J. M., Aragno, M., Matthey, W., 2004. The living soil: fundamentals of soil science and soil biology. Science Publishers.

He, Q., Walling, D., 1997. The distribution of fallout Cs-137 and Pb-210 in undisturbed and cultivated soils. App. Radiat. Isot. 48 (5), 677-690.

Hoogerkamp, M., Rogaar, H., Eijsackers, H. P., 1983. Effect of earthworms on grassland on recently reclaimed polder soils in the Netherlands. In Earthworm ecology (pp. 85-105). Springer Netherlands.

Jacobsen, O.H., Moldrup, P., Larson, C., Konnerup, L., Peteren, L.W., 1997. Particle transport in macropores of undisturbed soil columns. J. Hydrol. 196, 185-203.

Jamagne, M., 1973. Contribution à l'étude pédologique des formations loessiques du Nord de la France. Thèse de la faculté des sciences agronomiques de l'état, Gembloux Belgique 445 p. 
682 Jamagne, M., 1978. Soil-forming processes in a progressive evolutionary sequence on loessial

683

684

685

686

687

688

689

690

691

692

693

694

695

696

697

698

699

700

701

702

703 silty formation in a cold and humid temperate zone. Comptes Rendus Hebdomadaires des Séances de l'Académie des Sciences, Paris, 286 (1), 25-27.

Jamagne, M., Pedro, G., 1981. Les phénomènes de migration et d'accumulation de particules au cours de la pédogenèse sur les formations limoneuses du Nord de la France. Essai de caractérisation du processus de "lessivage". CRAS 292, 1329-1332.

James, S. W., 1991. Soil, nitrogen, phosphorus, and organic matter processing by earthworms in tall grass prairie. Ecology 2101-2109.

Jarvis, N. J., Taylor, A., Larsbo, M., Etana, A., Rosen, K., 2010. Modelling the effects of bioturbation on the re-distribution of $137 \mathrm{Cs}$ in an undisturbed grassland soil. Eur. J. Soil Sci. 61 (1), 24-34.

Jenny, H., 1941. Factors of soil formation. McGraw-Hill Book Company New York.

Jones, A., Montanarella, L., Jones, R, 2005. Soil atlas of Europe. European Commission.

Kjaergaard, C., De Jonge, L. W., Moldrup, P., Schjønning, P., 2004. Water-Dispersible Colloids. Vadose Zone J., 3(2), 403-412.

Khan, M.S.H., Parkash, B., Kumar, S., 2005. Soil-landform development of a part of the fold belt along the eastern coast of Bangladesh. Geomorphology 71, 310-327.

Kollmannsperger, F., 1934. Die Oligochaeten des Bellinchengebietes, eine ökologische, ethologische und tiergeographische Untersuchung (Doctoral dissertation, Druckerei W. May).

Kretzschmar, A., 1982. Description des galeries de vers de terre et variation saisonnière des réseaux (observations en conditions naturelles). Rev. Ecol. Biol. Sol 19 (4), 579-591. 
Kühn, P., 2003. Morphology and late glacial/Holocene genesis of Luvisols in MecklenburgVorpommern (NE-Germany). Catena 54, 53-555.

Le Bissonnais, Y., Arrouays, D., 1997. Aggregate stability and assessment of soil crustability and erodibility: II. Application to humic loamy soils with various organic carbon contents. Eur. J. Soil Sci. 48 (1), 39-48.

Lee, K. E., 1985. Earthworms, Their Ecology and Relationships with Soils and Land Use. Academic Press, Sydney.

Majdalani, S., Michel, E., Di Pietro, L., Angulo-Jaramillo, R., Rousseau, M., 2007. Mobilization and preferential transport of soil particles during infiltration: A core-scale modeling approach. Water Resour. Res. 43 (5).

Matisoff, G., Ketterer, M. E., Rosen, K., Mietelski, J. W., Vitko, L. F., Persson, H., Lokas, E., 2011. Downward migration of Chernobyl-derived radionuclides in soils in Poland and Sweden. Appl. Geochem. 26 (1), 105-115.

Matthey, W., Zettel, J., Bieri, M., 1990. Invertébrés bioindicateurs de la qualité des sols agricoles, Wirbellose Bodentiere als Bioindikatoren für die Qualität von Landwirtschaftsböden. Nationales Forschungsprogramm ‘Boden’ (NFP 22), Bericht Nr. 56, Liebefeld-Bern.

Montagne, D., Cousin, I., Josière, O., Cornu, S., 2013. Agricultural drainage-induced Albeluvisol evolution: A source of deterministic chaos. Geoderma 193, 109-116.

Müller-Lemans, H., van Dorp, F., 1996. Bioturbation as a mechanism for radionuclide transport in soil: Relevance of earthworms. J. Environ. Radioact. 31 (1), 7-20.

Munsell, A. H., 2000. Munsell soil color charts. Munsell Color. 
Persson, T., Lenoir, L., Taylor, A., 2007. Bioturbation in different ecosystems at Forsmark and Oskarhamn. SKB Rapport R-06-123. Stockholm Sweden.

Poesen, J. W., Verstraeten, G., Soenens, R., Seynaeve, L., 2001. Soil losses due to harvesting of chicory roots and sugar beet: an underrated geomorphic process? Catena 43 (1), 35-47.

Preiss, N., Mélières, M. A., Pourchet, M., 1996. A compilation of data on lead 210 concentration in surface air and fluxes at the air-surface and water-sediment interfaces. J. Geophy. Res. 101(D22), 28847-28862.

Quénard, L., Samouelian, A., Laroche, B., Cornu, S., 2011. Lessivage as a major process of soil formation: A revisitation of existing data. Geoderma 167-168, 135-147.

Reynolds, J. W., 1970. The relationship of earthworm (Oligochaeta:Lumbricidae and Medascolecidae) distribution and biomass to soil type in forest and grassland habitats at Oak Ridge National Laboratory. Assoc. Southeast Biology Bulletin, vol. 17, 60 pp.

Rodriguez, M. D., 2006. The bioturbation transport of chemicals in surface soils (Doctoral dissertation, Faculty of the Louisiana State University and Agricultural and Mechanical College.

Rosén, K., Öborn, I., Lönsjö, H., 1999. Migration of radiocaesium in Swedish soil profiles after the Chernobyl accident, 1987-1995. J. Environ. Radioact. 46 (1), 45-66.

Roussel-Debel, S., Renaud, P., Metivier, J. M., 2007. ${ }^{137}$ Cs in French soils: Deposition patterns and 15-year evolution. Sci. Total Environ. 374 (2), 388-398.

Sawhney, B., 1972. Selective sorption and fixation of cations by clay minerals: a review. Clays Clay Miner. 20, 93-100.

Schiffers, K., Teal, L. R., Travis, J. M. J., Solan, M., 2011. An open source simulation model for soil and sediment bioturbation. PloS ONE 6 (12), e28028. 
Schimmack,W., Feria Marquez, F., 2006. Migration of fallout radiocaesium in a grassland soil from 1986 to 2001 - Part II: Evaluation of the activity-depth profiles by transport models. Sci. Total Environ. 368 (2-3), 863-874.

Schmidt, M. W. I., Rumpel, C., Kögel- Knabner, I., 1999. Evaluation of an ultrasonic dispersion procedure to isolate primary organomineral complexes from soils. Eu. J. Soil Sci. 50 (1), 87-94.

Schuller, P., Bunzl, K., Voigt, G., Ellies, A., Castillo, A., 2004. Global fallout Cs-137 accumulation and vertical migration in selected soils from South Patagonia. J. Environ. Radioact. 71 (1), 43-60.

Schuller, P., Ellies, A., Kirchner, G., 1997. Vertical migration of fallout Cs-137 in agricultural soils from Southern Chile. Sci. Total Environ. 193 (3), 197-205.

Smith, J., Elder, D., 1999. A comparison of models for characterizing the distribution of radionuclides with depth in soils. Eur. J. Soil Sci. 50 (2), 295-307.

Stöckli, A., 1928. Studien über den Einfluss des Regenwurmes auf die Beschaffenheit des Bodens. Landwirtschuftliches Juhrbuch der Schweiz, 42 (1), 1-121 (Diss ETH 492, Zurich).

Syers, J. K., Sharpley, A. N., Keeney, D. R., 1979. Cycling of nitrogen by surface-casting earthworms in a pasture ecosystem. Soil Biol. Biochem., 11(2), 181-185.

Tamura, T., Jacobs, D., 1960. Structural implications in cesium sorption. Health Phys. 2 (4), $391-398$.

Ullrich, A., Volk, M., 2009. Application of the Soil and Water Assessment Tool (SWAT) to predict the impact of alternative management practices on water quality and quantity. Agric. Water Manag. 96 (8), 1207-1217. 
772 Van Breemen, N., Buuerman, P., 2002. Soil formation. Springer.

773 Van Oost, K., Cerdan, O., Quine, T. A., 2009. Accelerated sediment fluxes by water and tillage erosion on European agricultural land. Earth Surf. Process. Landforms 34 (12), 1625-

775 1634.

776

777

778

779

780

781

782

783

784

785

786

787

788 and $\mathrm{F}$ - forest.

Wilkinson, M. T., Richards, P. J., Humphreys, G. S., 2009. Breaking ground: Pedological, geological, and ecological implications of soil bioturbation. Earth-Science Reviews 97 $(1-4), 257-272$.

Figure 1: Observed and modeled distributions of ${ }^{137} \mathrm{Cs}$ under three land uses at each of the studied sites. The modeling duration for the Mons and Feucherolles sites was from 1954 to 2011 (57 years) and for the Boigneville site from 1954 to 2012 (58 years). In the legend: cDiff constant diffusion, vDiff - variable diffusion, cVel - constant velocity, and vVel - variable velocity. No diffusion coefficient was used to simulate the tilled plots.

Figure 2: Organic carbon content and the index of clay migration according to $\mathrm{pH}$ (IMCpH). CT - conventional tillage, RT - reduced tillage, NT - no tillage, MI - manure input, G - grassland,

Figure 3: Comparison of the mean diffusion coefficients calculated for the upper $30 \mathrm{~cm}$, the 791 mean convection velocities calculated for the upper $40 \mathrm{~cm}$ and the annual erosion rates with the 792 different model settings. CT - conventional tillage; RT - reduced tillage; NT - no tillage; MI 793 manure input, G - grassland, F - forest, nDiff - no diffusion, cDiff - constant diffusion, vDiff - 
794 variable diffusion (no diffusion for tilled plots), cVel - constant velocity, and vVel - variable 795 velocity.

797 Figure 4: Comparison of ${ }^{210} \mathrm{~Pb}(\mathrm{xs})$ in the fraction coarser than $2 \mu \mathrm{m}$ and organic carbon in the 798 fraction coarser than $2 \mu \mathrm{m}$ in the surface samples.

799 Figure 5: Modeling results of the ${ }^{210} \mathrm{~Pb}(\mathrm{xs})$ distributions in the bulk soil samples (left and middle 800 figures) and in the $0-2 \mu \mathrm{m}$ fraction for the forest (figure at right). Modeling duration was from 8011700 to 2011 (311 years). cDiff - constant diffusion, vDiff - variable diffusion, cVel - constant 802 velocity, vVel - variable velocity.

803 Table 1: General description of the studied sites.

804 Table 2: Synthetic soil description of the different plots and sites.

805 Table 3: Pedologic characteristics of the studied sites.

806 Table 4: Modeling setup (with/without erosion and diffusion) and initial parameters for fallout 807 due to the Chernobyl accident in $1986\left(a_{C h}\right)$, tillage depth $\left(T_{D}\right)$ and mixing ratio induced by the 808 tillage $\left(M_{R}\right)$. Models with variable convection velocities simulate the change in the velocity as 809 segment-lines, with fixed endpoint depths specifically determined for each site according to its 810 pedologic characteristics.

811 Table 5: ${ }^{137} \mathrm{Cs}$ and ${ }^{210} \mathrm{~Pb}(\mathrm{xs})$ inventories on the sampling date.

812 Table 6: ${ }^{137} \mathrm{Cs}$ and ${ }^{210} \mathrm{~Pb}(\mathrm{xs})$ activities measured by gamma spectroscopy in the $\leq 2 \mu \mathrm{m}$ size 813 fraction. The ratio of activities in the $\leq 2 \mu \mathrm{m}$ fraction to the total activities in the bulk soil sample 814 is expressed as a $\%$. $<\mathrm{DL}-$ below the detection limit 
815 Table 7: Modeling results of the ${ }^{137}$ Cs vertical distribution in the studied soils. The modeling was 816 performed either without or with diffusion (constant or exponentially decreasing) and with 817 constant convection velocity. $D_{0}$ - diffusion coefficient at the surface, $D_{s}$ - diffusion coefficient, $b$ 818 - parameter of exponentially decreasing diffusion, $v_{s}$ - convection velocity coefficient, $E$ - erosion 819 parameter, $E F$ - modeling efficiency, $R S S$ - residual sum of squares, $S D$ - standard deviation, \pm 820 uncertainty, CT - conventional tillage, RT - reduced tillage, NT - no tillage and MI - manure 821 input.

822 Table 8: Modeling results of the ${ }^{137}$ Cs vertical distribution in studied soils. The modeling was 823 performed either without or with diffusion (exponentially decreasing) and with variable 824 convection velocity. $D_{0}$ - diffusion coefficient at the surface, $D_{s}$ - diffusion coefficient, $b$ 825 parameter of exponentially decreasing diffusion, $v_{0}$ - convection velocity at the surface, $v_{1}$ 826 convection velocity at a given endpoint (depth $z$ in parenthesis), $v_{2}$ - convection velocity at a 827 given endpoint (depth $z$ in parenthesis), $v_{s}$ - convection velocity coefficient, $E$ - erosion 828 parameter, $E F$ - modeling efficiency, $R S S$ - residual sum of squares, $S D$ - standard-deviation, \pm 829 uncertainty, CT - conventional tillage, RT - reduced tillage, NT - no tillage and MI - manure 830 input.

831 Table 9: Bioturbation rates and surface cast rates generated by earthworms in the soil under 832 deciduous forests and grasslands in a humid temperate climate. 
Table 1: General description of the studied sites.

\begin{tabular}{|c|c|c|c|}
\hline Site & Mons & Feucherolles & Boigneville \\
\hline Experiment name & $\begin{array}{l}\text { Essay system - ORE-ACBB }{ }^{\mathrm{a}} \\
\text { Mons }\end{array}$ & ORE-PRO $^{\mathrm{b}}$-Qualiagro & Wheat monoculture \\
\hline Managing institution & INRA & INRA & Arvalis (Plant institute) \\
\hline Geographic coordinates & $49^{\circ} 52^{\prime} 01^{\prime \prime} \mathrm{N}-3^{\circ} 01^{\prime} 53^{\prime \prime} \mathrm{E}$ & $48^{\circ} 53^{\prime} 49^{\prime \prime} \mathrm{N}-1^{\circ} 58^{\prime} 19^{\prime \prime} \mathrm{E}$ & $\begin{array}{l}2^{\circ} 22^{\prime} 58^{\prime \prime} \mathrm{E} \\
48^{\circ} 19^{\prime} 30^{\prime} \mathrm{N}\end{array}$ \\
\hline Elevation & $88 \mathrm{~m}$ & $120 \mathrm{~m}$ & $116 \mathrm{~m}$ \\
\hline Mean annual rainfall & $680 \mathrm{~mm}$ & $660 \mathrm{~mm}$ & $630 \mathrm{~mm}$ \\
\hline $\begin{array}{l}\text { Mean annual } \\
\text { temperature }\end{array}$ & $11^{\circ} \mathrm{C}$ & $11.2^{\circ} \mathrm{C}$ & $10.4^{\circ} \mathrm{C}$ \\
\hline $\begin{array}{l}\text { Considered landuses and } \\
\text { farming practices }\end{array}$ & $\begin{array}{ll}\text { - } & \text { Conventional tillage } \\
\text { - } & \text { Reduced tillage (since } \\
\text { 2000) } \\
\text { - } \text { Grassland (since 1939) }\end{array}$ & 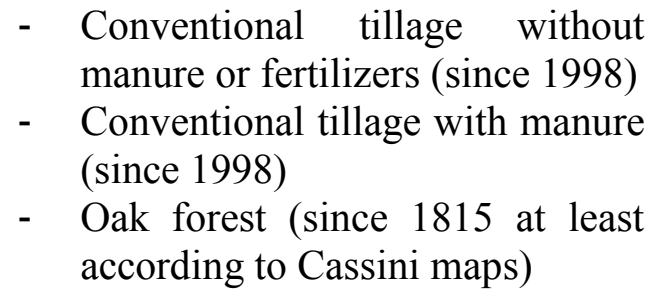 & $\begin{array}{ll}\text { - } & \text { Conventional tillage } \\
\text { - } & \text { Reduced tillage (since } \\
\text { 1970) } \\
\text { - }\end{array}$ \\
\hline Crop rotation & Wheat - corn - sugarbeet & Corn - wheat & Wheat \\
\hline Liming & $\begin{array}{l}\text { Not since } 1986 \text { under } \\
\text { cultivation and } 1939 \text { for } \\
\text { pasture }\end{array}$ & Not since 1998 under cultivation & Not since 1970 \\
\hline $\begin{array}{l}\text { Maximal distance } \\
\text { among plots }\end{array}$ & $2 \mathrm{~km}$ & $2 \mathrm{~km}$ & A few tens of meters \\
\hline Sampling date & March 2011 & April 2011 & March 2012 \\
\hline
\end{tabular}


Table 2: Synthetic soil description of the different plots and sites.

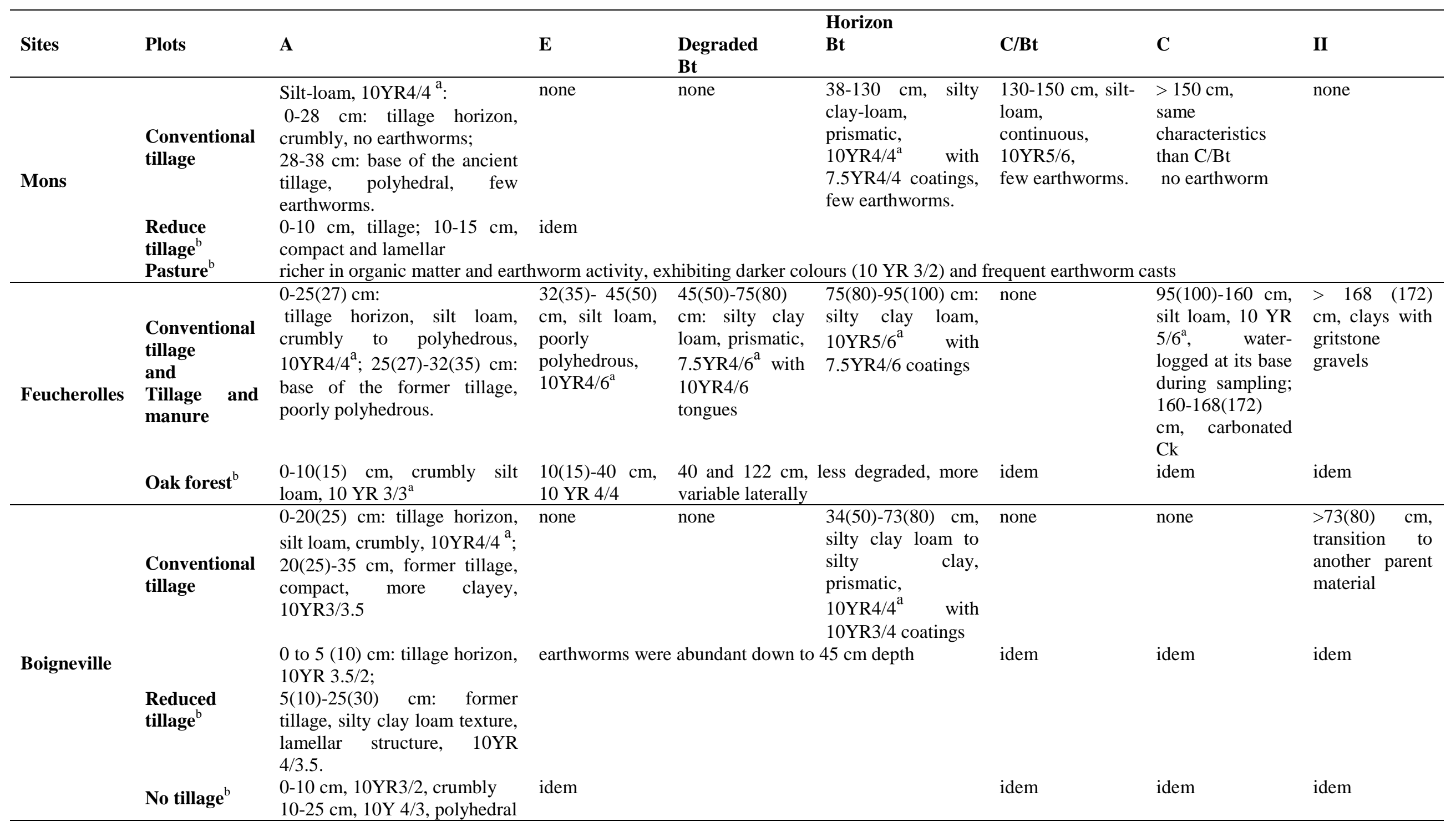


a according to the Munsell Soil Color Chart, 2000

${ }^{\mathrm{b}}$ only changes compared to the reference tilled profile of the same site were described 
Table 3: Pedologic characteristics of the studied sites.

\begin{tabular}{|c|c|c|c|c|c|c|c|c|c|c|c|}
\hline \multirow[t]{2}{*}{ Horizon } & \multirow{2}{*}{$\begin{array}{c}\text { Depths } \\
\text { cm }\end{array}$} & \multicolumn{5}{|c|}{ Particle size in $\mathrm{g} \mathrm{kg}^{-1}$} & \multirow{2}{*}{$\begin{array}{c}\text { Organic } \\
\text { carbon } \\
\mathrm{g} \mathrm{kg}^{-1}\end{array}$} & \multirow{2}{*}{$\begin{array}{c}\text { pH } \\
\left(\mathbf{H}_{2} \mathbf{O}\right)\end{array}$} & \multirow{2}{*}{$\begin{array}{c}\text { CEC } \\
\operatorname{cmol}(+) k^{-1}\end{array}$} & \multirow{2}{*}{$\begin{array}{c}\mathrm{CaCO}_{3} \text { total } \\
\mathrm{g} \mathrm{kg}^{-1}\end{array}$} & \multirow{2}{*}{$\begin{array}{c}\text { Bulk density } \\
\mathrm{g} \mathrm{cm}^{-3}\end{array}$} \\
\hline & & $0-2 \mu \mathrm{m}$ & $2-20 \mu \mathrm{m}$ & 20-50 $\mu \mathrm{m}$ & $50-200 \mu \mathrm{m}$ & $200-2000 \mu \mathrm{m}$ & & & & & \\
\hline \multicolumn{12}{|c|}{ Mons: Conventional Tillage } \\
\hline Ap & $0-27$ & 192 & 315 & 435 & 46 & 12 & 11.8 & 7.84 & 11.9 & $<1$ & 1.40 \\
\hline A2 & $27-37$ & 219 & 315 & 414 & 44 & 8 & 9.0 & 8.05 & 12.5 & $<1$ & 1.43 \\
\hline $\mathrm{Bt} 1-\mathrm{Bt} 3$ & $37-125$ & 287 & 279 & 395 & 37 & 3 & 2.8 & 8.09 & 15.8 & $<1$ & 1.50 \\
\hline $\mathrm{C} / \mathrm{Bt}$ & $125-145$ & 219 & 227 & 530 & 23 & 2 & 1.7 & 8.15 & 12.9 & $<1$ & 1.42 \\
\hline $\mathrm{C}$ & $145-155$ & 184 & 224 & 575 & 16 & 1 & 1.3 & 8.07 & 11.0 & $<1$ & 1.36 \\
\hline \multicolumn{12}{|c|}{ Mons: Reduced Tillage } \\
\hline Ap & $0-10$ & 212 & 301 & 428 & 51 & 9 & 12.9 & 7.34 & 11.5 & $<1$ & 1.34 \\
\hline $\mathrm{A} 2$ & $10-15$ & 207 & 308 & 431 & 48 & 7 & 10.2 & 7.76 & 11.3 & $<1$ & 1.49 \\
\hline A3 & $15-42$ & 206 & 316 & 424 & 45 & 8 & 9.4 & 8.00 & 11.8 & $<1$ & 1.50 \\
\hline $\mathrm{Bt} 1-\mathrm{Bt} 3$ & $42-125$ & 260 & 260 & 436 & 42 & 2 & 2.6 & 8.04 & 14.7 & $<1$ & 1.48 \\
\hline $\mathrm{C} / \mathrm{Bt}$ & $125-145$ & 209 & 226 & 544 & 20 & 2 & 1.5 & 7.87 & 12.0 & $<1$ & 1.41 \\
\hline $\mathrm{C}$ & $145-155$ & 192 & 237 & 558 & 12 & 1 & 1.1 & 8.00 & 10.7 & $<1$ & 1.37 \\
\hline \multicolumn{12}{|c|}{ Mons: Grassland } \\
\hline A1 & $0-10$ & 202 & 303 & 438 & 46 & 11 & 28.6 & 6.07 & 14.1 & $<1$ & 1.20 \\
\hline A2 & $10-40$ & 201 & 307 & 432 & 49 & 12 & 14.5 & 6.68 & 13.7 & $<1$ & 1.39 \\
\hline $\mathrm{Bt} 1-\mathrm{Bt} 3$ & $40-102$ & 277 & 300 & 376 & 42 & 4 & 3.8 & 7.27 & 16.4 & $<1$ & 1.50 \\
\hline $\mathrm{C} / \mathrm{Bt}$ & $102-142$ & 244 & 221 & 493 & 40 & 3 & 1.7 & 7.51 & 15.5 & $<1$ & 1.45 \\
\hline $\mathrm{C}$ & $142-162$ & 190 & 255 & 537 & 17 & 2 & 1.3 & 7.56 & 11.9 & $<1$ & 1.38 \\
\hline \multicolumn{12}{|c|}{ Feucherolles: Conventional tillage } \\
\hline Ap & $0-25$ & 142 & 296 & 495 & 54 & 13 & 9.4 & 6.59 & 7.7 & $<1$ & 1.36 \\
\hline A2 & $25-31$ & 144 & 300 & 483 & 61 & 13 & 9.5 & 6.61 & 7.9 & $<1$ & 1.41 \\
\hline $\mathrm{E}$ & $31-50$ & 211 & 295 & 430 & 46 & 19 & 3.8 & 6.99 & 9.4 & $<1$ & 1.48 \\
\hline Btgd & $50-75$ & 298 & 268 & 384 & 38 & 12 & 2.6 & 7.34 & 14.3 & $<1$ & 1.53 \\
\hline $\mathrm{Bt} 2$ & $75-95$ & 331 & 208 & 437 & 22 & 3 & 2.1 & 7.43 & 18.4 & $<1$ & 1.51 \\
\hline $\mathrm{C} / \mathrm{Bt}$ & $95-145$ & 244 & 236 & 492 & 26 & 2 & 1.3 & 7.63 & 14.5 & $<1$ & 1.51 \\
\hline
\end{tabular}


C $145-165$

207

270

493

Particle size in $\mathrm{g} \mathrm{kg}^{-1}$

0-2 $\mu \mathrm{m} \quad 2-20 \mu \mathrm{m}$

Feucherolles: Conventional tillage and manure

$\begin{array}{cccc}\text { Ap } & 0-25 & 144 & 296 \\ \text { A2 } & 25-33 & 145 & 292 \\ \text { E } & 33-50 & 192 & 290 \\ \text { Btgd } & 50-80 & 305 & 253 \\ \text { Bt2 } & 80-100 & 309 & 201 \\ \text { C } & 100-160 & 225 & 260 \\ \text { Ck } & 160-170 & 194 & 255\end{array}$

$\begin{array}{ccc}\text { A } & 0-10 & 176 \\ \text { E } & 10-40 & 167 \\ \text { Bt1-Bt2 } & 40-95 & 228 \\ \text { Bt3 } & 95-125 & 305 \\ \text { C } & 125-147 & 243 \\ \text { Ck } & 147-157 & 137\end{array}$

$\begin{array}{ccc}\text { Ap } & 0-24 & 256 \\ \text { E } & 24-35 & 263 \\ \text { Bt1 } & 35-80 & 375 \\ \text { II } & 80-100 & 177\end{array}$

$\begin{array}{ccc}\text { Ap } & 0-5 & 256 \\ \text { Ap2 } & 5-31 & 264 \\ \text { Bt1-Bt2 } & 31-74 & 371 \\ \text { II } & 74-95 & 176\end{array}$

284

288

281

196

248

240

306

305

286

188

\begin{abstract}
489
\end{abstract}
491
455

455
400

469

459

343

463

463

420

465

484

457

357

354

300

118

\section{3}

298

280
271
26

4

1.3

Organic carbon

$\mathrm{g} \mathrm{kg}^{-1}$

14.0
10.0
5.0
2.7
1.9
1.7
0.9

pH

$\left(\mathrm{H}_{2} \mathrm{O}\right)$

$$
\begin{aligned}
& 7.27 \\
& 7.38 \\
& 7.45 \\
& 7.56 \\
& 7.49 \\
& 7.49 \\
& 8.53
\end{aligned}
$$

\section{Feucherolles: Oak forest}

$\begin{array}{lccc}64 & 13 & 30.5 & 5.55 \\ 66 & 17 & 10.9 & 5.12 \\ 55 & 16 & 3.2 & 5.72 \\ 28 & 6 & 1.9 & 6.23 \\ 24 & 2 & 2.0 & 6.84 \\ 19 & 2 & 0.9 & 8.55\end{array}$

$<1$

1.54

Boigneville: Conventional Tillage

$\begin{array}{lcccccc}63 & 19 & 12.1 & 6.91 & 14.9 & <1 & 1.35 \\ 62 & 17 & 9.1 & 7.28 & 15.6 & <1 & 1.45 \\ 33 & 6 & 3.9 & 7.85 & 21.6 & 3.07 & 1.50 \\ 38 & 5 & 2.5 & 8.87 & 11.0 & 467.5 & 1.47\end{array}$

Boigneville: Reduced Tillage

$\begin{array}{lcccccc}60 & 19 & 24.9 & 6.09 & 13.2 & <1 & 1.26 \\ 62 & 18 & 11.8 & 6.71 & 14.5 & <1 & 1.41 \\ 42 & 8 & 4.6 & 7.75 & 21.1 & 1.68 & 1.51 \\ 57 & 6 & 4.4 & 8.71 & 16.2 & 334 & 1.47\end{array}$




\begin{tabular}{|c|c|c|c|c|c|c|c|c|c|c|c|}
\hline \multirow[t]{3}{*}{ Horizon } & \multirow{3}{*}{$\begin{array}{c}\text { Depths } \\
\text { cm }\end{array}$} & \multicolumn{5}{|c|}{ Particle size in $\mathrm{g} \mathrm{kg}^{-1}$} & \multirow{2}{*}{$\begin{array}{l}\text { Organic } \\
\text { carbon } \\
\mathrm{g} \mathrm{kg}^{-1}\end{array}$} & \multirow{2}{*}{$\begin{array}{c}\mathbf{p H} \\
\left(\mathbf{H}_{2} \mathbf{O}\right)\end{array}$} & \multirow{2}{*}{$\begin{array}{c}\text { CEC } \\
\operatorname{cmol}(+) \mathrm{kg}^{-1}\end{array}$} & \multirow{2}{*}{$\begin{array}{c}\mathrm{CaCO}_{3} \text { total } \\
\mathrm{g} \mathrm{kg}^{-1}\end{array}$} & \multirow{2}{*}{$\begin{array}{c}\text { Bulk density } \\
\qquad \mathrm{g} \mathrm{cm}^{-3}\end{array}$} \\
\hline & & $0-2 \mu \mathrm{m}$ & $2-20 \mu \mathrm{m}$ & $20-50 \mu \mathrm{m}$ & $50-200 \mu \mathrm{m}$ & $200-2000 \mu \mathrm{m}$ & & & & & \\
\hline & & \multicolumn{10}{|c|}{ Boigneville: No-tillage } \\
\hline A & $0-10$ & 238 & 302 & 364 & 71 & 24 & 24.4 & 5.69 & 12.1 & $<1$ & 1.24 \\
\hline $\mathrm{A} 2$ & $10-25$ & 249 & 299 & 359 & 70 & 24 & 10.4 & 6.87 & 14.1 & $<1$ & 1.53 \\
\hline $\mathrm{E}$ & $25-45$ & 328 & 295 & 317 & 47 & 13 & 6.0 & 7.43 & 17.1 & $<1$ & 1.49 \\
\hline $\mathrm{Bt}$ & $45-80$ & 377 & 288 & 293 & 34 & 8 & 3.6 & 7.77 & 20.9 & 2 & 1.50 \\
\hline II & $80-100$ & 212 & 227 & 87 & 42 & 5 & 3.2 & 8.84 & 12.3 & 421.5 & 1.47 \\
\hline
\end{tabular}


Table 4: Modeling setup (with/without erosion and diffusion) and initial parameters for fallout due to the Chernobyl accident in $1986\left(a_{C h}\right)$, tillage depth $\left(T_{D}\right)$ and mixing ratio induced by the tillage $\left(M_{R}\right)$. Models with variable convection velocities simulate the change in the velocity as segment-lines, with fixed endpoint depths specifically determined for each site according to its pedologic characteristics.

\begin{tabular}{|c|c|c|c|c|c|c|}
\hline \multirow[t]{2}{*}{ Site } & \multirow[t]{2}{*}{ Erosion } & \multirow[t]{2}{*}{ Diffusion } & \multirow[t]{2}{*}{ 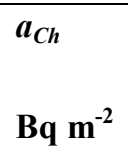 } & \multirow[t]{2}{*}{$\begin{array}{l}T_{D} \\
\mathrm{~cm}\end{array}$} & \multirow[t]{2}{*}{$M_{R}$} & \multirow[t]{2}{*}{$\begin{array}{l}\text { Fixed end- } \\
\text { point depth } \\
\text { cm }\end{array}$} \\
\hline & & & & & & \\
\hline $\begin{array}{l}\text { Mons: Conventional } \\
\text { tillage }\end{array}$ & Yes & No & 661 & 28 & 0.85 & 0 and 20 \\
\hline Mons: Reduced tillage & Yes & No & 661 & $\begin{array}{l}28(1954- \\
1999) \\
10(2000- \\
2011)\end{array}$ & $\begin{array}{l}0.85(1954- \\
1999) \\
0.30(2000- \\
2011)\end{array}$ & $\begin{array}{l}0 \text { and } 20 \text { and } \\
40\end{array}$ \\
\hline Mons: Grassland & No & Yes & 661 & - & - & $\begin{array}{l}0 \text { and } 40 \text { and } \\
100\end{array}$ \\
\hline $\begin{array}{l}\text { Feucherolles: } \\
\text { Conventional tillage }\end{array}$ & Yes & No & 413 & 25 & 0.85 & $\begin{array}{l}0 \text { and } 20 \text { and } \\
80\end{array}$ \\
\hline Feucherolles: Manure & Yes & No & 413 & 25 & 0.85 & 0 and 40 \\
\hline Feucherolles : Oak forest & No & Yes & 413 & - & - & $\begin{array}{l}0 \text { and } 20 \text { and } \\
40\end{array}$ \\
\hline $\begin{array}{l}\text { Boigneville: } \\
\text { Conventional tillage }\end{array}$ & Yes & No & 499 & $\begin{array}{l}25(1954- \\
1999) \\
20(2000- \\
2012)\end{array}$ & $\begin{array}{l}0.85(1954- \\
1999) \\
0.85(2000- \\
2012)\end{array}$ & $\begin{array}{l}0 \text { and } 26 \text { and } \\
40\end{array}$ \\
\hline $\begin{array}{l}\text { Boigneville: Reduced } \\
\text { tillage }\end{array}$ & Yes & No & 499 & $\begin{array}{l}23(1954- \\
1969) \\
10(1970- \\
1999) \\
5(2000-2012)\end{array}$ & $\begin{array}{l}0.85(1954- \\
1969) \\
0.30(1970- \\
1999) \\
0.30(2000- \\
2012)\end{array}$ & $\begin{array}{l}0 \text { and } 14 \text { and } \\
30\end{array}$ \\
\hline Boigneville: No tillage & Yes & $\begin{array}{l}\text { Yes } \\
\text { (since } \\
1970)\end{array}$ & 499 & $\begin{array}{l}23(1954- \\
1969) \\
-(1970- \\
2012)\end{array}$ & $\begin{array}{l}0.85(1954- \\
1969) \\
-(1970- \\
2012)\end{array}$ & $\begin{array}{l}0 \text { and } 14 \text { and } \\
30\end{array}$ \\
\hline
\end{tabular}


Table 5: ${ }^{137} \mathrm{Cs}$ and ${ }^{210} \mathrm{~Pb}(\mathrm{xs})$ inventories on the sampling date.

\begin{tabular}{|c|c|c|c|c|c|}
\hline Site & Plot & $\begin{array}{c}{ }^{137} \mathrm{Cs} \\
\text { inventory } \\
\mathrm{Bq}^{-2} \\
\end{array}$ & $\begin{array}{l}\text { Error } \\
\mathrm{Bq} \mathrm{m}^{-2}\end{array}$ & $\begin{array}{c}{ }^{210} \mathrm{~Pb}(\mathrm{xs}) \\
\text { inventory } \\
\mathrm{Bq}^{-2}\end{array}$ & $\begin{array}{c}\text { Error } \\
\text { Bq } \mathbf{m}^{-2} \\
\end{array}$ \\
\hline \multirow[t]{3}{*}{ Mons } & $\begin{array}{l}\text { Conventional } \\
\text { tillage }\end{array}$ & 1419 & 129 & & \\
\hline & Reduced tillage & 1505 & 155 & 938 & 504 \\
\hline & Grassland & 2075 & 184 & 1548 & 1377 \\
\hline \multirow[t]{3}{*}{ Feuchehrolles } & $\begin{array}{l}\text { Conventional } \\
\text { tillage }\end{array}$ & 1451 & 167 & & \\
\hline & $\begin{array}{l}\text { Tillage and } \\
\text { manure }\end{array}$ & 1556 & 111 & 1478 & 747 \\
\hline & Oak forest & 1878 & 217 & 1921 & 1959 \\
\hline \multirow[t]{3}{*}{ Boigneville } & $\begin{array}{l}\text { Conventional } \\
\text { tillage }\end{array}$ & 1736 & 182 & & \\
\hline & Reduced tillage & 1518 & 138 & 1067 & 621 \\
\hline & No-tillage & 1479 & 183 & 813 & 735 \\
\hline
\end{tabular}


Table 6: ${ }^{137} \mathrm{Cs}$ and ${ }^{210} \mathrm{~Pb}(\mathrm{xs})$ activities measured by gamma spectroscopy in the $0-2 \mu \mathrm{m}$ size fraction. The ratio of activities in the $0-2 \mu \mathrm{m}$ fraction to the total activities in the bulk soil sample is expressed as a $\%$. $<\mathrm{DL}$ - below the detection limit

\begin{tabular}{|c|c|c|c|c|c|c|c|c|c|}
\hline $\begin{array}{c}\text { Depths } \\
\text { cm }\end{array}$ & $\begin{array}{c}{ }^{137} \mathrm{Cs} \\
0-2 \mu \mathrm{m} \\
\mathrm{Bq} \mathrm{kg}^{-1}\end{array}$ & $\mathrm{~Bq} \mathrm{~kg}{ }^{-1}$ & $\begin{array}{c}{ }^{210} \mathrm{~Pb}(\mathrm{xs}) \\
0-2 \mu \mathrm{m} \\
\mathrm{Bq} \mathrm{kg}^{-1}\end{array}$ & $\mathrm{~Bq} \mathrm{~kg}^{-1}$ & $\begin{array}{c}\text { Clay } \\
(0-2 \mu \mathrm{m}) \\
\mathrm{g} \mathrm{kg}^{-1}\end{array}$ & $\begin{array}{c}{ }^{137} \mathrm{Cs} \\
\% \mathrm{o-2} \mu \mathrm{m} \\
\text { in bulk } \\
\%\end{array}$ & Error & $\begin{array}{c}{ }^{210} \mathrm{~Pb}(\mathrm{xs}) \\
\% 0-2 \mu \mathrm{m} \\
\text { in bulk } \\
\%\end{array}$ & Error \\
\hline \multicolumn{10}{|c|}{ Mons: Reduced Tillage } \\
\hline 5-10 & 10.3 & 0.7 & 38 & 6 & 208 & 72 & 13 & 135 & 70 \\
\hline $12-15$ & 14.2 & 0.8 & 26 & 6 & 206 & 93 & 15 & $>100$ & - \\
\hline $25-30$ & 14.7 & 0.6 & 32 & 4 & 208 & 103 & 16 & $>100$ & - \\
\hline
\end{tabular}

\section{Mons: Conventional}

Tillage

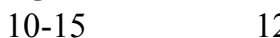

$33-35$

12.1

0.7

0.7
0.5

36
$<$

$\begin{array}{ll}5 & 203 \\ 9 & 234\end{array}$

$\begin{array}{lll}82 & 13 & >100\end{array}$

Mons: Grassland

$\begin{array}{crrr}0-2 & 18.5 & 0.8 & 45 \\ 2-4 & 18.3 & 0.8 & 30 \\ 18-20 & 18.4 & 0.5 & 29 \\ 45-50 & 1.2 & 0.5\end{array}$

Feucherolles: Conventional Tillage

$\begin{array}{llrl}10-15 & 20.7 & 0.7 & 39 \\ 27-29 & 20.3 & 0.5\end{array}$

27-29

20.3

0.5

39
38

$\begin{array}{ll}4 & 142 \\ 3 & 145\end{array}$

86

88

$\begin{array}{ll}11 & >100 \\ 11 & >100\end{array}$

Feucherolles: Manure

$\begin{array}{rrrrrrrrrr}10-15 & 22.1 & 0.6 & 43 & 4 & 145 & 102 & 14 & 148 & 90 \\ 27-29 & 21.3 & 0.8 & 33 & 5 & 146 & 93 & 11 & 116 & 63 \\ 33-35 & 12.7 & 0.5 & 24 & 4 & 149 & 96 & 17 & >100 & -\end{array}$


Feucherolles: Oak

forest

$\begin{array}{rrrrrrrrrr}0-2 & 41.5 & 1.3 & 92 & 8 & 185 & 99 & 12 & 52 & 11 \\ 2-4 & 41.6 & 1.2 & 83 & 7 & 180 & 97 & 11 & 87 & 23 \\ 16-18 & 36.3 & 1.0 & 15 & 5 & 170 & 92 & 10 & >100 & - \\ 40-45 & \leq & 0.8 & 10 & 4 & 213 & <\text { DL } & - & >100\end{array}$

Boigneville: Conventional Tillage

\begin{tabular}{|c|c|c|c|c|c|c|c|c|c|}
\hline $5-10$ & 14.2 & 0.9 & $\leq$ & 13 & 260 & 92 & 16 & $<\mathrm{DL}$ & - \\
\hline $31-33$ & 9.8 & 0.9 & $\leq$ & 14 & 262 & 97 & 22 & $<\mathrm{DL}$ & - \\
\hline \multicolumn{10}{|c|}{ igneville: Reduced Tillage } \\
\hline $0-5$ & 16.5 & 0.7 & 41 & 5 & 256 & 93 & 13 & 80 & 28 \\
\hline $13-15$ & 14.9 & 0.5 & $\leq$ & 6 & 270 & 106 & 13 & $<\mathrm{DL}$ & - \\
\hline \multicolumn{10}{|c|}{ igneville: No tillage } \\
\hline $0-2$ & 19.1 & 0.8 & 54 & 6 & 235 & 106 & 16 & 63 & 22 \\
\hline $2-4$ & 19.2 & 0.8 & 38 & 5 & 229 & 91 & 13 & 55 & 24 \\
\hline $18-20$ & 11.9 & 0.6 & $\leq$ & 8 & 250 & 78 & 11 & $<\mathrm{DL}$ & - \\
\hline
\end{tabular}


Table 7: Modeling results of the ${ }^{137} \mathrm{Cs}$ vertical distribution in the studied soils. The modeling was performed either without or with diffusion (constant or exponentially decreasing) and with constant convection velocity. $D_{0}$ - diffusion coefficient at the surface, $D_{s}$ - diffusion coefficient, $b$ - parameter of exponentially decreasing diffusion, $v_{s}$ - convection velocity coefficient, $E$ - erosion parameter, EF - modeling efficiency, $R S S$ residual sum of squares, $S D$ - standard deviation, \pm uncertainty, CT - conventional tillage, RT - reduced tillage, NT - no tillage and MI - manure input.

\begin{tabular}{|c|c|c|c|c|c|c|c|c|c|c|c|c|c|c|c|c|}
\hline Site & $\begin{array}{c}D_{0} \\
\mathrm{~cm}^{2} \mathrm{yr}^{-1}\end{array}$ & $\mathrm{~cm}^{2} \mathrm{yr}^{-1}$ & $b$ & SD & $\begin{array}{c}\text { Mean } D_{s} \\
\left(0-30 \mathrm{~cm}^{-}\right) \\
\mathrm{cm}^{2} \mathrm{yr}^{-1}\end{array}$ & $\mathrm{~cm}^{2} \mathrm{yr}^{-1}$ & $\begin{array}{c}v_{s} \\
\mathrm{~cm}^{-1} \\
\mathrm{yr}^{-1}\end{array}$ & $\begin{array}{l}\text { SD } \\
\text { cm } \\
\mathrm{yr}^{-1}\end{array}$ & $10^{-3} \mathrm{~cm}$ & $\begin{array}{l}\text { SD } \\
\\
10^{-3} \\
\mathrm{~cm} \\
\end{array}$ & $E F$ & $R S S 10^{-6}$ & $\begin{array}{l}\mathbf{m m} \\
\mathrm{yr}^{-1}\end{array}$ & $\begin{array}{c}\text { Annt } \\
\pm \\
\mathbf{m m} \\
\mathbf{y r}^{-1}\end{array}$ & l erosion & $\begin{array}{c} \pm \\
\mathrm{tha}^{-1} \\
\mathrm{yr}^{-1}\end{array}$ \\
\hline \multicolumn{17}{|l|}{ Without diffusion } \\
\hline Mons: CT & - & - & - & - & - & - & 0.14 & 0.005 & 14.06 & 0.65 & 0.99 & 4.7 & 0.70 & 0.16 & 9.80 & 2.43 \\
\hline Mons: RT & - & - & - & - & - & - & 0.15 & 0.006 & 11.85 & 0.98 & 0.98 & 13.3 & 0.59 & 0.24 & 8.10 & 3.48 \\
\hline Feucherolles: CT & - & - & - & - & - & - & 0.13 & 0.006 & 9.88 & 0.79 & 0.99 & 9.7 & 0.49 & 0.20 & 6.77 & 2.82 \\
\hline Feucherolles: CT + MI & - & - & - & - & - & - & 0.23 & 0.005 & 6.45 & 0.84 & 0.98 & 13.6 & 0.32 & 0.21 & 4.23 & 2.82 \\
\hline Boigneville: CT & - & - & - & - & - & - & 0.18 & 0.008 & 2.74 & 0.93 & 0.98 & 18.7 & 0.14 & 0.24 & 1.81 & 3.10 \\
\hline Boigneville: RT & - & - & - & - & - & - & 0.09 & 0.003 & 5.00 & 0.59 & 0.97 & 11.2 & 0.25 & 0.15 & 2.73 & 1.66 \\
\hline \multicolumn{17}{|l|}{ Constant diffusion } \\
\hline Boigneville: NT & 0.13 & 0.08 & - & - & - & - & 0.08 & 0.01 & 7.35 & 2.34 & 0.80 & 79.0 & 0.37 & 0.59 & 4.41 & 7.09 \\
\hline Feucherolles: Oak forest & 1.10 & 0.22 & - & - & - & - & 0.14 & 0.02 & - & - & 0.78 & 110.0 & - & - & - & - \\
\hline Mons: Grassland & 2.55 & 0.27 & - & - & - & - & 0.29 & 0.02 & - & - & 0.96 & 31.7 & - & - & - & - \\
\hline \multicolumn{17}{|l|}{ Variable diffusion } \\
\hline Boigneville: NT & 0.001 & 0.001 & 1.00 & 1.32 & $3.33 \mathrm{E}-05$ & 7.73E-05 & 0.07 & 0.003 & 3.36 & 0.74 & 0.95 & 8.2 & 0.17 & 0.19 & 2.02 & 2.26 \\
\hline Mons: Grassland & 5.42 & 1.81 & 0.04 & 0.01 & 3.16 & 1.92 & 0.26 & 0.02 & - & - & 0.97 & 19.6 & - & - & - & - \\
\hline
\end{tabular}


Table 8: Modeling results of the ${ }^{137} \mathrm{Cs}$ vertical distribution in studied soils. The modeling was performed either without or with diffusion (exponentially decreasing) and with variable convection velocity. $D_{0}$ - diffusion coefficient at the surface, $D_{s}$ - diffusion coefficient, $b$ - parameter of exponentially decreasing diffusion, $v_{0}$ - convection velocity at the surface, $v_{l}$ - convection velocity at a given endpoint (depth $z$ in parenthesis), $v_{2}$ - convection velocity at a given endpoint (depth $z$ in parenthesis), $v_{s}$ - convection velocity coefficient, $E$ - erosion parameter, $E F$ - modeling efficiency, RSS - residual sum of squares, $S D$ - standard-deviation, \pm uncertainty, CT - conventional tillage, RT - reduced tillage, NT - no tillage and MI - manure input.

\begin{tabular}{|c|c|c|c|c|c|c|c|c|c|c|c|c|c|c|c|c|c|c|c|c|c|c|}
\hline Site & $\begin{array}{c}D_{0} \\
\mathbf{c m}^{2} \\
\mathbf{y r}^{-1}\end{array}$ & $\begin{array}{l}\text { SD } \\
\mathbf{c m}^{2} \\
\mathbf{y r}^{-1}\end{array}$ & $b$ & SD & $\begin{array}{c}\text { Mean } \\
D_{s} \\
(0-30 \\
\mathbf{c m}^{2} \\
\mathrm{~cm}^{2} \\
\mathrm{yr}^{-1} \\
\end{array}$ & $\begin{array}{l}\text { SD } \\
\mathbf{c m}^{2} \\
\mathbf{y r}^{-1}\end{array}$ & $\begin{array}{c}v_{0} \\
(\mathrm{z}=0)\end{array}$ & $\begin{array}{c}\mathbf{c m} \\
\mathbf{y r}^{-1}\end{array}$ & $\mathrm{~cm} \mathrm{yr}_{1}^{-}$ & $\begin{array}{c}\mathrm{cm} \\
\mathrm{yr}^{-1}\end{array}$ & $\mathrm{~cm} \mathrm{yr}^{-1}$ & $\begin{array}{c}\mathrm{cm} \\
\mathrm{yr}^{-1}\end{array}$ & $\begin{array}{c}\text { Mean } \\
v_{s} \\
(0-40 \\
\mathrm{cm}) \\
\mathrm{cm} \\
\mathrm{yr}^{-1} \\
\end{array}$ & $\begin{array}{c}\mathrm{cm} \\
\mathrm{yr}^{-1}\end{array}$ & $\begin{array}{c}E \\
10^{-3} \\
\mathrm{~cm}\end{array}$ & $\begin{array}{l}10^{-3} \\
\mathrm{~cm}\end{array}$ & $E F$ & $R S S 10^{-6}$ & $\begin{array}{l}\mathbf{m m} \\
\mathrm{yr}^{-1}\end{array}$ & $\begin{array}{c} \pm \\
\mathbf{m m} \\
\mathbf{y r}^{-1} \\
\end{array}$ & $\begin{array}{c}\mathrm{t} \mathrm{ha}^{-1} \\
\mathrm{yr}^{-1}\end{array}$ & $\begin{array}{c} \pm \\
\mathrm{t} \mathrm{ha}^{-1} \\
\mathrm{yr}^{-1}\end{array}$ \\
\hline \multicolumn{23}{|l|}{ Without diffusion } \\
\hline Mons: CT & - & - & - & - & - & - & 0.03 & 0.15 & $\begin{array}{c}0.14 \\
(z=20) \\
0.12\end{array}$ & 0.006 & $\overline{0.19}$ & - & 0.11 & 0.16 & 14.02 & 0.68 & 0.99 & 4.39 & 0.70 & 0.17 & 9.80 & 2.54 \\
\hline Mons: RT & - & - & - & - & - & - & 0.23 & 0.05 & $\begin{array}{c}(\mathrm{z}=20) \\
0.12\end{array}$ & 0.02 & $\begin{array}{c}(\mathrm{z}=40) \\
0.24\end{array}$ & 0.03 & 0.16 & 0.10 & 11.50 & 0.91 & 0.99 & 8.92 & 0.58 & 0.23 & 7.96 & 3.28 \\
\hline $\begin{array}{l}\text { Feucherolles : CT } \\
\text { Feucherolles: CT }+\end{array}$ & - & - & - & - & - & - & 0.00 & 1.28 & $(\mathrm{z}=20)$ & 0.02 & $\begin{array}{c}(\mathrm{z}=80) \\
0.29\end{array}$ & 0.17 & 0.1 & 1.47 & 9.99 & 0.89 & 0.99 & 9.09 & 0.50 & 0.22 & 6.99 & 3.23 \\
\hline MI & - & - & - & - & - & - & 0.09 & 0.05 & $\overline{0.17}$ & - & $\begin{array}{c}(\mathrm{z}=40) \\
0.25\end{array}$ & 0.02 & 0.19 & 0.07 & 6.94 & 0.65 & 0.99 & 6.66 & 0.35 & 0.16 & 4.86 & 2.36 \\
\hline Boigneville: CT & - & - & - & - & - & - & 0.05 & 0.08 & $\begin{array}{c}(\mathrm{z}=26) \\
0.09\end{array}$ & 0.01 & $\begin{array}{c}(\mathrm{z}=40) \\
0.09\end{array}$ & 0.04 & 0.14 & 0.13 & 2.89 & 0.68 & 0.99 & 6.96 & 0.14 & 0.16 & 1.91 & 2.28 \\
\hline $\begin{array}{l}\text { Boigneville: RT } \\
\text { Variable diffusion }\end{array}$ & - & - & - & - & & & 0.1 & 0.02 & $(\mathrm{z}=14)$ & 0.01 & $(\mathrm{z}=30)$ & 0.01 & 0.09 & 0.04 & 4.75 & 0.63 & 0.97 & 9.51 & 0.24 & 0.16 & 2.59 & 1.76 \\
\hline $\begin{array}{l}\text { Boigneville: NT } \\
\text { Feucherolles: Oak }\end{array}$ & 0.0003 & 0.002 & 0.46 & 74.3 & $\begin{array}{l}2.17 \mathrm{E}- \\
05\end{array}$ & 0.0038 & 0.06 & 0.07 & $\begin{array}{c}0.05 \\
(z=14) \\
0.09\end{array}$ & 0.03 & $\begin{array}{c}0.08 \\
(\mathrm{z}=30) \\
2.06\end{array}$ & 0.02 & 0.06 & 0.12 & 2.47 & 3.82 & 0.99 & 2.90 & 0.12 & 0.93 & 1.48 & 11.47 \\
\hline forest & 45.16 & 130.26 & 0.26 & 0.07 & 5.79 & 18.25 & 0.18 & 0.29 & $\begin{array}{c}(z=20) \\
0.71\end{array}$ & 0.32 & $\begin{array}{c}(\mathrm{z}=40) \\
0\end{array}$ & 1.15 & 0.59 & 1.76 & - & - & 0.97 & 15.2 & - & - & - & - \\
\hline Mons: Grassland & 3.68 & 2.04 & 0.08 & 0.10 & 1.39 & 2.63 & 0.18 & 0.08 & $(\mathrm{z}=40)$ & 0.56 & $(z=100)$ & 3.07 & 0.44 & 0.64 & 一 & 一 & 0.98 & 18.3 & - & - & - & - \\
\hline
\end{tabular}


Table 9: Bioturbation rates and surface cast rates generated by earthworms in the soil under deciduous forest and pasture for humid temperate climate.

\begin{tabular}{|c|c|c|c|c|c|c|}
\hline Land use & References & Location & Earthworm type & $\begin{array}{l}\text { Biomass } \\
\mathrm{g} \mathrm{m}^{-2}\end{array}$ & $\begin{array}{l}\text { Bioturbation } \\
\mathrm{t} \mathrm{ha}^{-1} \mathrm{yr}^{-1}\end{array}$ & $\begin{array}{l}\text { Surface cast } \\
\text { t ha }^{-1} \mathrm{yr}^{-2}\end{array}$ \\
\hline \multicolumn{7}{|c|}{ Deciduous forest } \\
\hline & Kollmannsperger (1934) & Germany & Lumbricidae & & & 68 \\
\hline & Persson et al. (2007) & Sweden & Endogeic, epigeic & $4-35$ & $40-420$ & $0.8-5$ \\
\hline & Reynolds (1970) & Tennessee (USA) & Lumbricidae & $1.3-14$ & $2.6-28^{\mathrm{a}}$ & \\
\hline & Rodriguez (2006) & Germany & Lumbricidae & & & 58 \\
\hline \multicolumn{7}{|l|}{ Grassland } \\
\hline & Anderson $(1988)$ & UK & & & & $40-50$ \\
\hline & $\begin{array}{l}\text { Bieri and Cuendet (1989) in Müller-Lemans and van Dorp, } \\
\text { (1996) }\end{array}$ & Switzerland & Anecic $80 \%$ & 270 & $432^{\mathrm{b}}$ & \\
\hline & Bouché (1981) in Müller-Lemans and van Dorp, (1996) & France & Anecic $80 \%$ & 121 & $193.6^{\mathrm{b}}$ & 60 \\
\hline & Bouché (1982) & France & Lumbricidae & 165.4 & $330.8^{\mathrm{a}}$ & 7 \\
\hline & Darwin $(1881)$ & UK & & & & 44.7 \\
\hline & $\begin{array}{l}\text { Edwards and Lofty (1977) in Müller-Lemans and van Dorp, } \\
\text { (1996) }\end{array}$ & & & & & 91.4 \\
\hline & Gobat et al. (2004) & Switzerland & & & & $18-81$ \\
\hline & Gobat et al. (2004) & UK & & & & 91 \\
\hline & Gobat et al. (2004) & Germany & & & & $19-40$ \\
\hline & $\begin{array}{l}\text { Hoogerkamp et al. (1983) in Müller-Lemans and van Dorp, } \\
\text { (1996) }\end{array}$ & The Netherlands & Anecic $80 \%$ & 250 & $400^{\mathrm{b}}$ & \\
\hline & James (1991) & Kansas (USA) & $\begin{array}{l}\text { Diplocardia spp and } \\
\text { Lumbricidae }\end{array}$ & $\begin{array}{c}1.44 \pm 1.35 \text { and } \\
1.39 \pm 2.23\end{array}$ & $5.7 \pm 7.2^{\mathrm{a}}$ & 1.91 \\
\hline & James $(1991)$ & Kansas (USA) & $\begin{array}{l}\text { Diplocardia spp and } \\
\text { Lumbricidae }\end{array}$ & $\begin{array}{c}0.95 \pm 0.54 \text { and } \\
4.43 \pm 3.6\end{array}$ & $10.8 \pm 8.3^{\mathrm{a}}$ & 2.81 \\
\hline & $\begin{array}{l}\text { Kretzschmar (1982) in Müller-Lemans and van Dorp, } \\
\text { (1996) }\end{array}$ & France & Anecic $80 \%$ & 200 & $320^{b}$ & $29-134$ \\
\hline & Lee (1985) in Müller-Lemans and van Dorp, (1996) & UK & Anecic $80 \%$ & 149 & $238.4^{\mathrm{b}}$ & \\
\hline & Lee (1985) in Müller-Lemans and van Dorp, (1996) & France & Anecic $80 \%$ & 165.4 & $264.6^{\mathrm{b}}$ & 70 \\
\hline & Lee (1985) in Müller-Lemans and van Dorp, (1996) & Germany & Anecic $80 \%$ & 96.5 & $154.4^{\mathrm{b}}$ & \\
\hline & $\begin{array}{l}\text { Matthey et al. (1990) in Müller-Lemans and van Dorp, } \\
\text { (1996) }\end{array}$ & Switzerland & Anecic $80 \%$ & $34-272$ & $54.4-435.2^{b}$ & \\
\hline
\end{tabular}




\begin{tabular}{lllc} 
Persson et al. (2007) & Sweden & Endogeic, epigeic & $10-30$ \\
Reynolds (1970) & Tennessee (USA) & Lumbricidae & $3.2-7.5$ \\
Stöckli (1928) in Müller-Lemans and van Dorp, (1996) & Switzerland & & $6.4-15^{\text {a }}$ \\
Stöckli (1928) in Müller-Lemans and van Dorp, (1996) & Switzerland & & $24.7-44.1$ \\
Syers et al. (1979) & New Zealand & $31.8-36$ \\
\hline
\end{tabular}

${ }^{a}$ Bioturbation calculated after Bouché (1981): anecic earthworm biomass $\left(\mathrm{g} \mathrm{m}^{-2}\right)$ x 200 (consumption of equivalent dry matter per year) $=$ bioturbation rate $\left(\mathrm{g} \mathrm{m}^{-2} \mathrm{yr}^{-1}\right)$

${ }^{\mathrm{b}}$ Bioturbation calculated after Bouché (1981) with hypothesis that anecic species represent in average $80 \%$ of total biomass (Müller-Lemans and van Dorp, 1996)

${ }^{c}$ Bioturbation estimated on the base of the earthworm surface rejections (casts). Although classical (Gobat et al., 2004), this method only considers the surface rejections and thus underestimates bioturbation (Persson et al., 2007). 

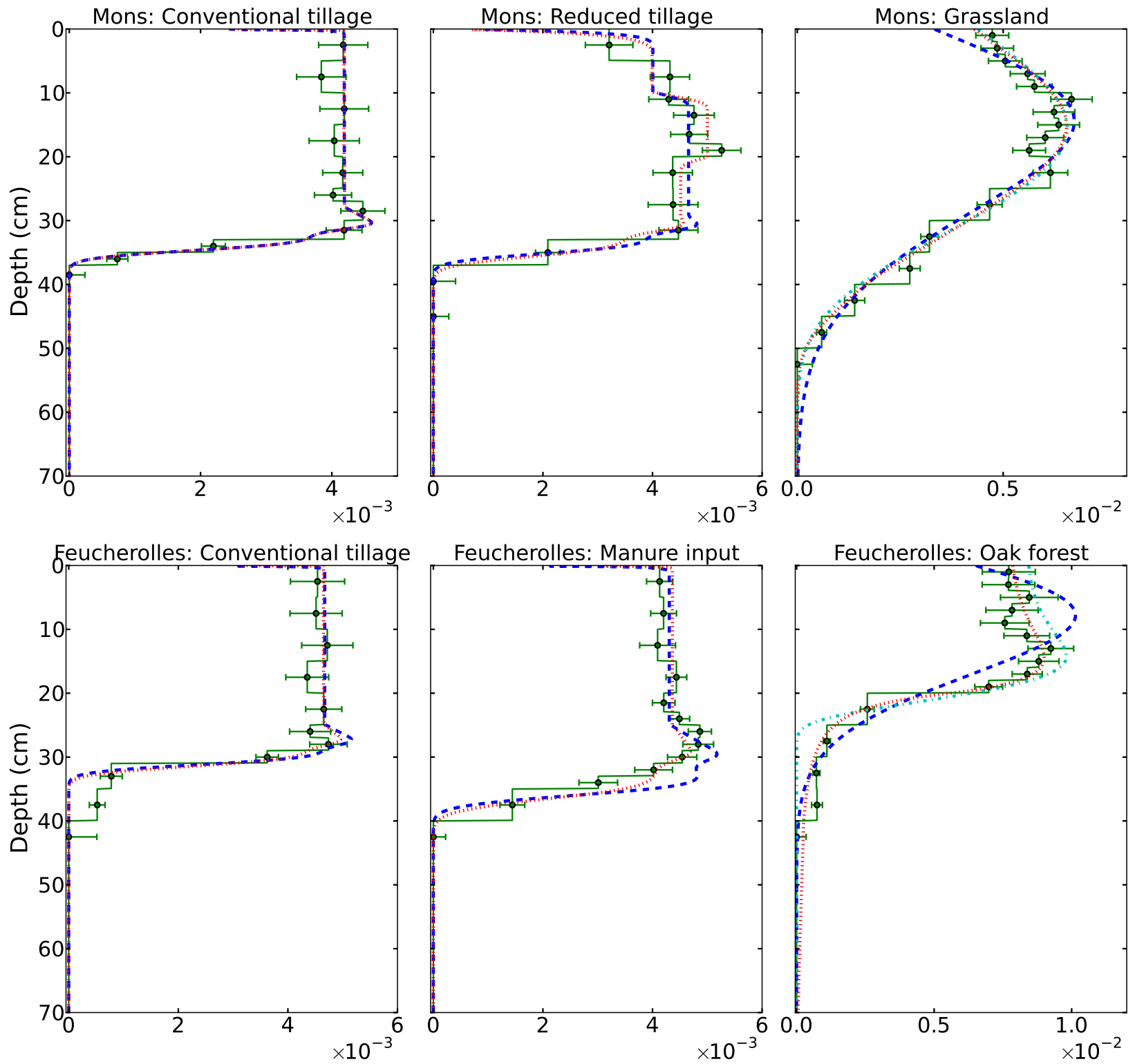

Feucherolles: Manure input

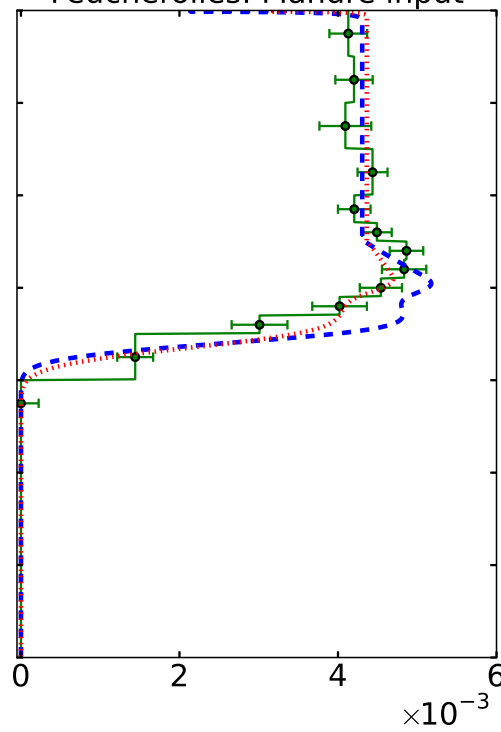

Feucherolles: Oak forest
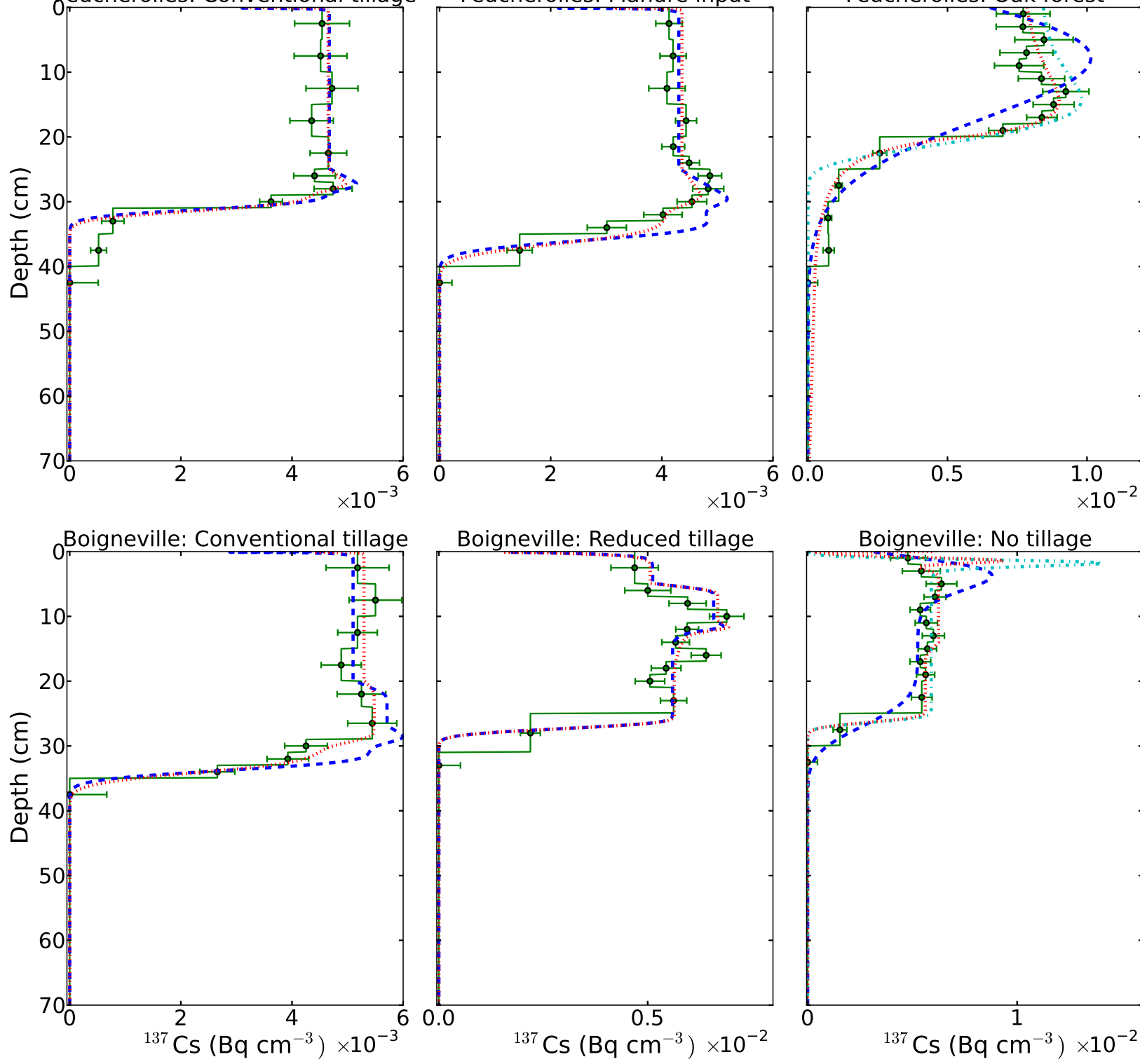

Boigneville: Reduced tillage

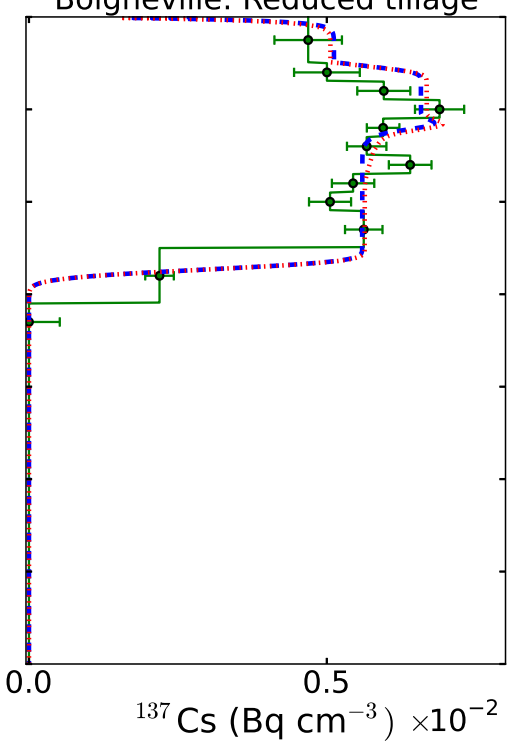

Boigneville: No tillage

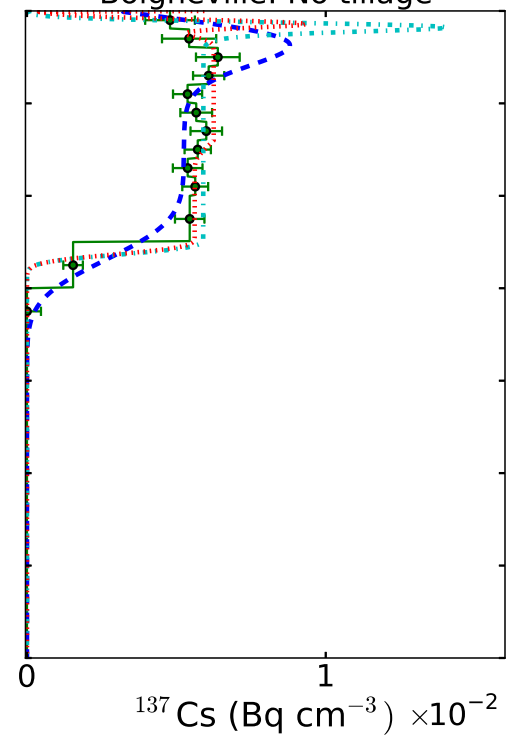



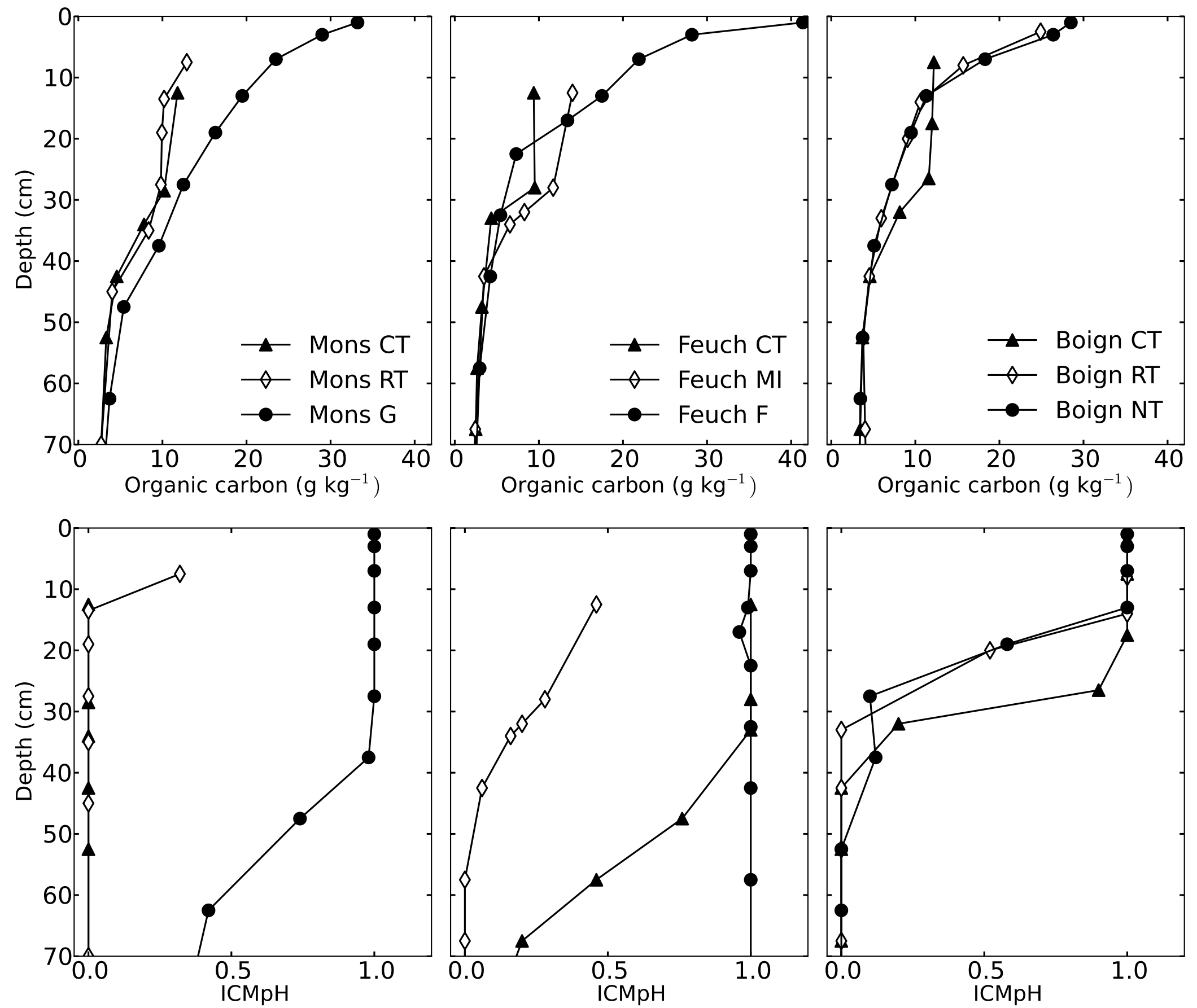
Figure 3
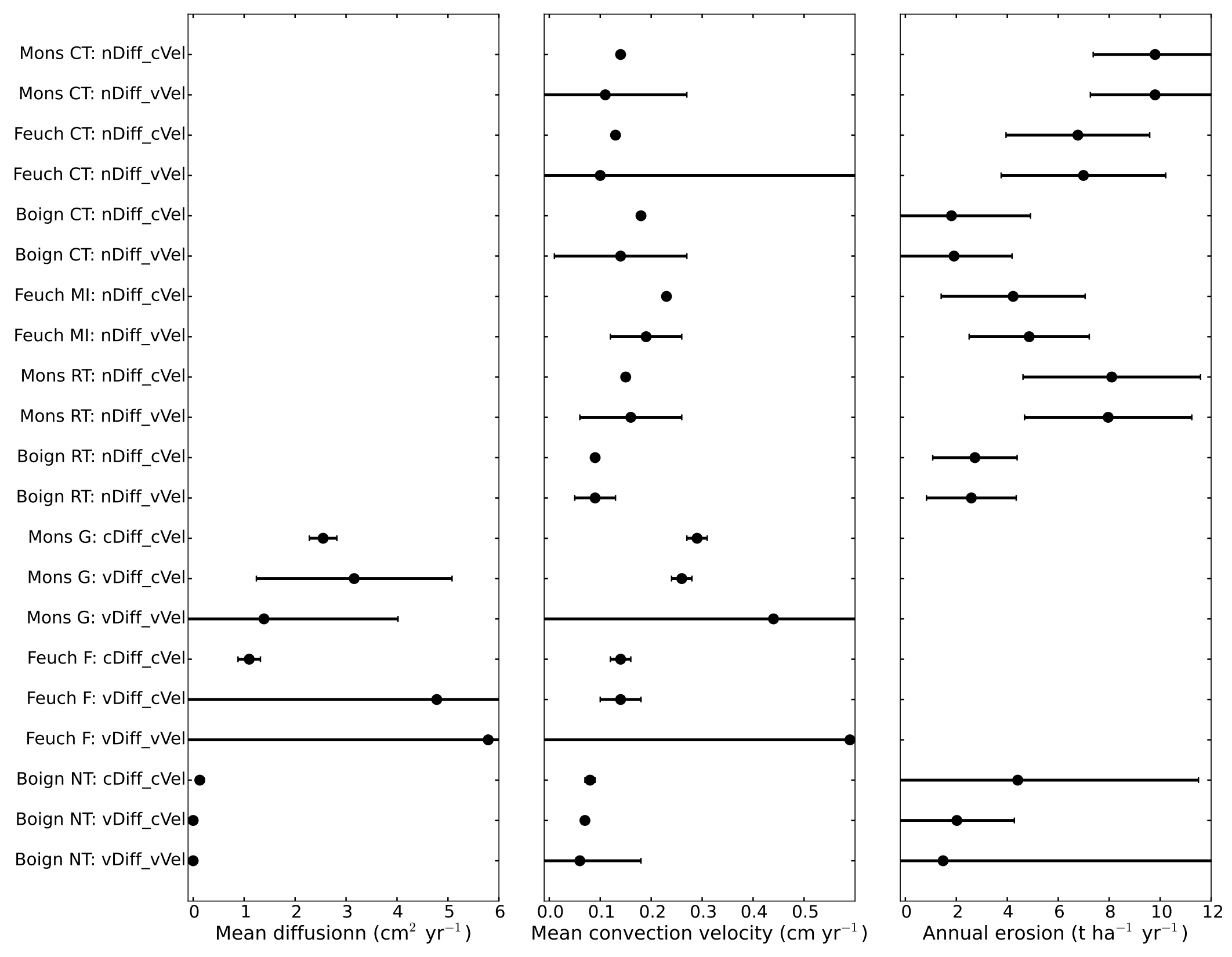
Figure 5

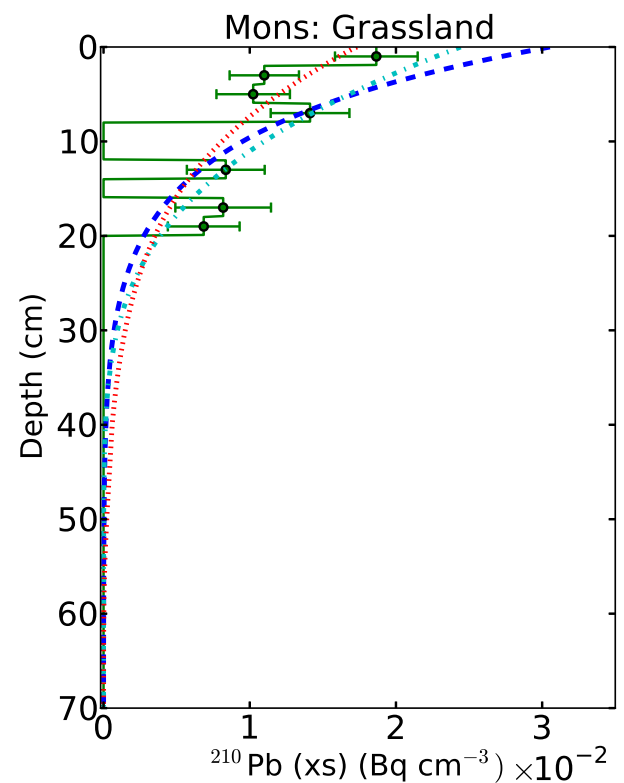

Feucherolles: Oak forest

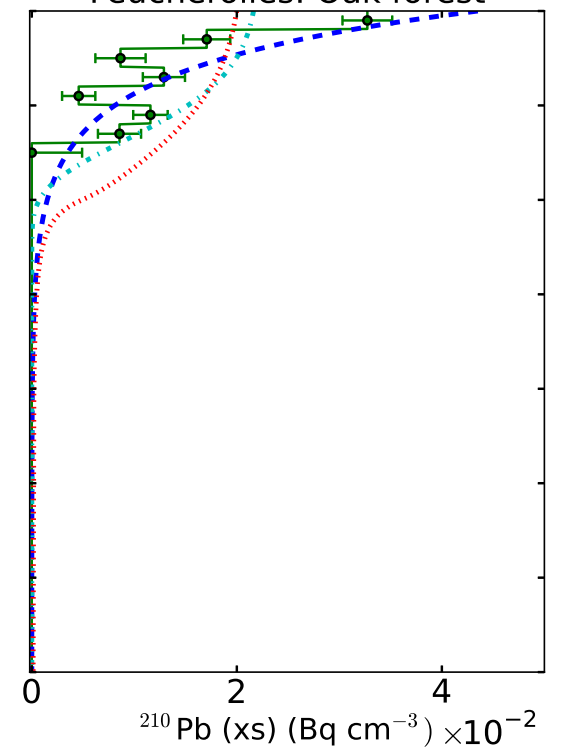

Feucherolles: Oak forest $(0-2 \mu \mathrm{m})$

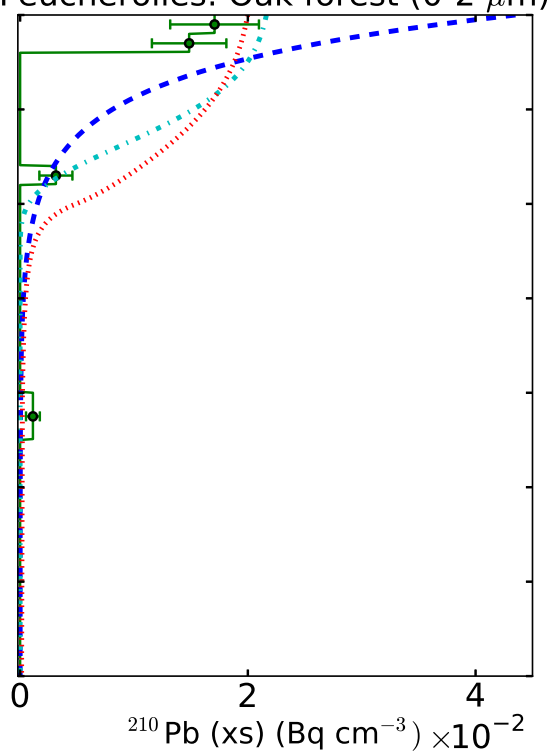

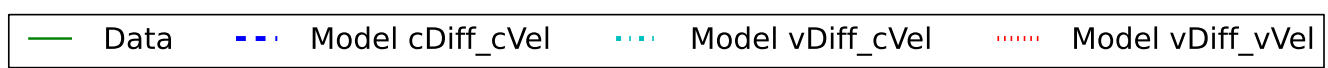


Supplementary Files
Click here to downloa

Supplementary Files
Click here to download Supplementary Files: AnnexA.docx

Click here to download Supplementary Files: AnnexA.docx (1)

(a)

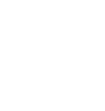

(n)

(1)

(1)

(1)

(1)

(1)

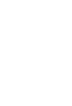

